九州㐘会誌 40 (6) : 1269 1296, 1986 .

\title{
乳歯根管充填材料が歯根膜および後継永久歯 歯肧に及ぼす影響に関する実験的研究
}

\author{
九州歯科大学小児歯科学講座（指導：木村光孝教授） \\ 九州䨑科大学口腔病理学講座 (指導 : 上野正康教授) \\ 井手口蓑
}

昭和 61 年 10 月 23 日受付

\section{An Experimental Study on the Effect of Deciduous Root Canal Filling Materials on the Periodontal Membrane and Succeeding Permanent Tooth Buds}

Susumu Ideguchi

\begin{abstract}
Department of Pedodontics (Director: Prof. Mitsutaka Kimura)
Department of Oral Pathology (Director: Prof. Masayasu Ueno)

Kyushu Dental College, Kitakyushu, Japan
\end{abstract}

Effect of deciduous root canal filling materials, Calvital, Vitapex, Kri I, Neodyne and FR, on the periodontal membrane and succeeding permanent tooth buds was investigated histopathologically with use of young dogs about three months old.

The results were as follows:

1. The subjects treated with Calvital showed almost no inflammatory changes in the apical periodontal membrane of deciduous teeth. However, Vitapex, Kri I , Neodyne and FR caused inflammatory changes.

2. Resorption of deciduous root was delayed in all the subjects treated by root canal filling, in comparison with controls. In the subjects treated with Vitapex or Neodyne, bony ankylosis of the deciduous root and alveolar bone was observed.

3. With regard to changes in succeeding permanent tooth buds, no changes in the cells of enamel organ were observed in the subjects treated with Calvital. With Vitapex and FR, changes such as flattening, fusion, lytic changes, irregular arrangement, and atrophy were observed in the cells of enamel organ when the filling materials extravasated. With Kri I, the cells of enamel organ showed flattening and atrophy. With Neodyne irregular arrangement and atrophy of the cells of enamel organ were observed.

4. In comparison with controls, eruption of permanent teeth was delayed owing to inflammatory chages caused in the periodontal membrane, delayed resorption of deciduous roots, and changes in the cells of enamel organ.

5. With Vitapex and Neodyne, bony ankylosis in particular was seen and disturbance in eruption of permanent teeth was observed.

6. Calvital, FR, Vitapex, Kri I, and Neodyne, in the descending order, affected 
the periodontal membrane and the cells of enamel organ of succeeding permanent teeth buds.

7. Use of deciduous root canal filling materials in treatment of non-infected root canals greatly affect fhe periodontal membrane and succeeding permanent tooth buds when they are applied to immature teeth or when they extravaste beyond the apical foramen.

\section{Key words : Deciduous Tooth/Root Canal Filling Materials/Periodontal Membrane/ Succeeding Permanent Tooth/Tooth Bud/Young Dog}

\section{緒言}

近年，歯科材料の安全性評価が重要視され，生体に対 する安全性と有効性の評価をいかに行うべきか国内外に おいて関心が高まり，とくに生物学的評価基準が注目さ れている。

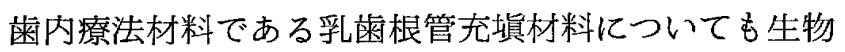
学的評価を行う必要がある. 日常の小坚歯科臨床におい て蒾髄疾患の診断基準から根管充填処置を施す症例は非 常に多い, 乳歯の根管充塡処置に関しては, 根管充媜材 料が霜根膜に対して刺激性が少なく, 親和性が良く, 治 癒促進作用を有することがとくに必要な条件であること は周知の通りである. 根管充填材料のもつ刺激が強度で あれば, 充填後, 乳歯の根尖蒾根膜に炎症を惹起し, 後 継永久歯歯胚に障害を起こすととにより，エナメル質减 形成などを引きおてす。

日常の小児柬科臨床で用いられている根管充填材料が 菌根膜に対してどのような影響を与えるか，また後継永 久蒾菌胚に対する為害性についても十分な検索がなされ ていないのが現状である.とくに乳曾の根管充壃材料の 生体適合性について十分な検索を行うことは, 歯根吸収 とともに材料が吸收性をもっているか，あるいは充媜材 料により何らかの障害を受けているかなど臨床を行うに あたって重要な意義をもっている，乳歯の各種根管充填 材料を同じ条件下で動物実験に用いた評価法を検索し た研究はほとんどないようである. Stanford (1980) ${ }^{11}$ は, 国際雨科連盟 (FDI), Working group 5 of the FDI Commission on Dental Products $(1983)^{21}$ は国 際標準化機構 (ISO), Stanley (1979） ${ }^{3)}$ は米国蒾科医 師会（ADA）に扔いて, 歯科材料の安全性試験基準, 生物学的評価基準を報告し, 我が国においても愿生科学 研究班のグループである佐藤 $(1985)^{4)}$ は 現時点で適当 と考える菌科材料の安全性試験項目を作成している。乙 の中で同研究班の木村ら (1986) ${ }^{51}$ は乳歯根管充填材料の
生物学的評価のための検索にあたっては，乳雬根の完成

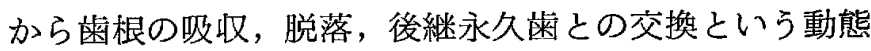
の全過程を包含している生後 3 力月前後の幼犬を実験に 使用するてとが適切であると報告している．

そこで著者は, 乳霜に用いる根管充填材料が㐘根膜お よび後継永久雪歯肧にどのような影響を及ぼしているか を詳細にわたって検索を行うため，動物実験による病理 組織学的検索を行った．その結果，いささかの知見を得 たので報告する.

\section{実験材料および方法}

実験に用いた根管充塤材料は, 日常の小児菌科臨床で 用いられている Calvital, Vitapex, Kri I, Neodyne for Root Canal Filling (以下, Neodyne と略記), FR の 5 種類である. 処方は下記に示している通りであ る。

$\begin{array}{lr}\text { (1) Calvital } & \\ \text { Powder: } & \\ \text { Calcium hydroxide } & 78.5 \% \\ \text { Iodoform } & 20.0 \% \\ \text { Sulfathiazole } & 1.4 \% \\ \text { Guanofrasin } & 0.1 \% \\ \text { Liquid : } & \\ \text { T-caine } & 0.5 \% \\ \text { Propylene glycol } & 50.0 \% \\ \text { Distilled water } & 49.5 \% \\ \quad \text { (2) Vitapex } & \\ \text { Calcium hydroxide } & 30.3 \% \\ \text { Iodoform } & 40.4 \% \\ \text { Silicone oil } & 22.4 \% \\ \text { Others } & 6.9 \%\end{array}$

(3) Kri I （ヨードホルムパスタ 108） パラクロロフェノール $2.025 \%$ dl一カンフル $4.860 \%$ 
Table 1 Experimental period and number of case

\begin{tabular}{l|c|c|c|c|c|c}
\hline \hline Material Duration & Ist Week & 2nd Week & Ist Month & 2nd Month & 3rd Month & Total \\
\hline Calvital & $6(3)$ & $6(2)$ & $6(3)$ & $6(2)$ & $7(3)$ & $31(31)$ \\
Vitapex & $7(2)$ & $7(3)$ & $6(4)$ & $6(3)$ & $6(3)$ & $32(15)$ \\
Kri I & $6(2)$ & $7(2)$ & $7(2)$ & $7(2)$ & $6(2)$ & $33(10)$ \\
Neodyne & $6(3)$ & $7(3)$ & $6(3)$ & $6(3)$ & $7(2)$ & $32(14)$ \\
FR & $7(3)$ & $6(2)$ & $7(2)$ & $6(4)$ & $7(3)$ & $33(14)$ \\
\hline Total & $32(13)$ & $33(12)$ & $32(14)$ & $31(14)$ & $33(13)$ & $161(66)$ \\
\hline
\end{tabular}

Lーメントール

$1.215 \%$

ヨードホルム

$80.800 \%$

基剤精製ラノリン

$8.320 \%$

基剤グリセリン

$2.780 \%$

(4) Neodyne

Powder :

Zinc oxid $\quad 60.0 \%$

Rosin

Calcium hydroxide

$25.0 \%$

$15.0 \%$

Liquid :

Eugenol

$100.0 \%$

(5) F R

粉昘!

水酸化カルシウム

酸化亜鉛

硫酸バリウム

液剂:

グアヤコールとホルムアルデヒドの縮合物

生後 3 力月前後の雑種健康幼犬を実験に供した。実験 に用いた乳雬は, 左側下顎第 2 , 第 3 乳臼歯で, 反対側 同名歯を対照群として何ら処置を行わなかった．実験に 用いた幼犬は Table 1 に示しているように50頭で, 実験歯161例，対照米66例で計227例である。

実験にあたっては， sodium pentobalbital で静脈内 麻酔の全身麻酔下にて実験を行った . 左右の実験部位を $\mathrm{X}$ 線撮影したのち, 口腔内を $3 \%$ 過酸化水素水にて清掃 消毒を十分に行った。注水下でダイヤモンドバーを用い て蒾冠部エナメル質, 象牙質を削除し, 天蓋除去, 髄室 開拉をラウンドバーにて行った．抜骮有を行うにあたって 根管口部で夹髄を露出させ，クレンザーで歯髄を一塊と して摘出した。 その後 Kerr のリーマーにて根管拡大
後， $3 \%$ 過酸化水素水と $8 \sim 10 \%$ 次覀塩素酸ナトリウム で交互に洗浄し，さらに0.9\%生食水で清掃し，根管内を 滅菌綿栓にて乾燥させた. その後各種根管充填材料の処 方に従って操作し根管充填を行い, セメント董装後, ア マルガム充填を施し，X線撮影後すべてを完了した。

実験動物は術後 1 週， 2 週， 1 力月， 2 力月, 3 力月 の各実験期間飼育後静脈内注射により薬殺し, 直ちに下 龥骨を採取し，10\%中性ホルマリン液で固定した。 $5 \%$ 硝酸脱灰ののち通法に従ってセロイジン包埋後, $15 \mu \mathrm{m}$ 連続切片標本を作製し, Hematoxylin-Eosin 重染色, 渡辺鍍銀染色を施し鏡見した。

\section{実 験 成 纉}

病理組織学的所見

I. 対照群

術後 1 週 術後 2 週

乳歯根は一定の長さに達し，歯根象牙質は厚く形成さ れ，根尖部は数本の細い根管側枝を残して有細胞セメン ト質によって閉鎖されている。歯根膜腔はほぼ一定の幅 を保っており，根尖部に至るまで歯根膜線維束も規則正 しい配列を示し，それに伴って線維芽細胞も密に配列し ている. 歯根膜に面した bundle bone は一般に平坦で 辺縁には骨牙細胞の配列が認められる.乳雪の舌側には 菲薄な函槽骨を介して後継永久歯曾胚が存在している. 永久柬柬胚は, 㐘乳頭を覆って棈円形の核をもった一層 の円柱状の内エナメル上皮細胞が配列しており，乙の内 エナメル上皮細胞に隣接して立方形あるいは扁平な中間 層細胞，その内側には紡錘形あるいは星形を呈し, 細長 い細胞質突起をもった細胞, いわゆるエナメル䯣が存在 している.そしてェナメル器の外表をなす比較的扁平な 細胞か配列しており，乙れら内外エナメル上皮は萪頸部 
で互いに移行して一種の閉鎖囊すなわち Hertwig 上皮 鞘を形成している.エナメル器は結合組織からなる歯小 囊によってとりまかれている.エナメル質は未石灰化の 状態にあり，ヘマトキシリンに濃染している（Fig． 1 $\sim 3)$.

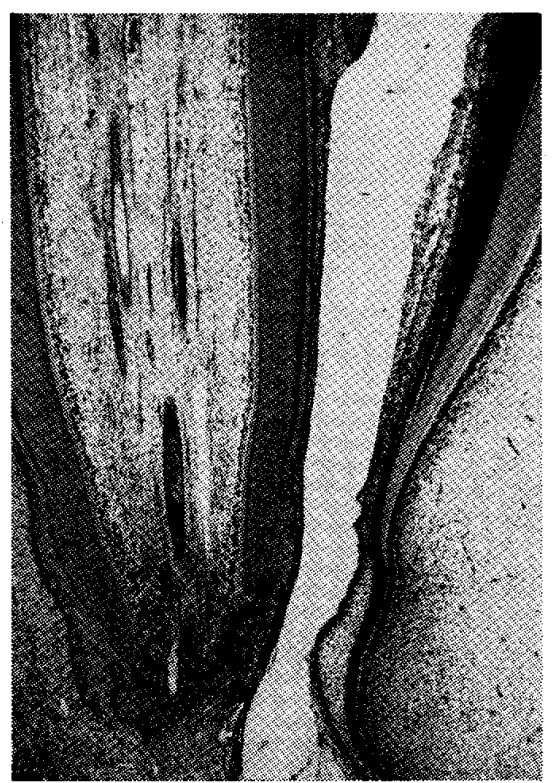

Fig. 1 Control

On the 7 th day

H.E. Stain $\times 20$

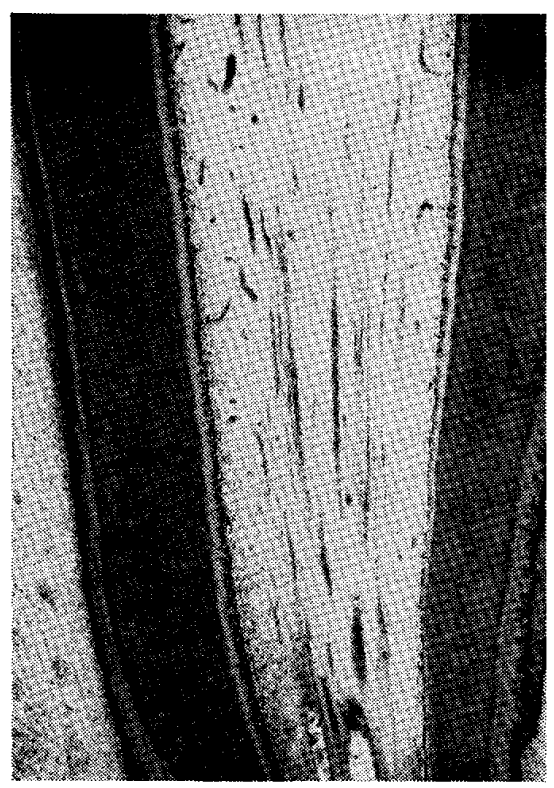

Fig. 2 Control

On the 14th day

H.E. Stain $\times 20$

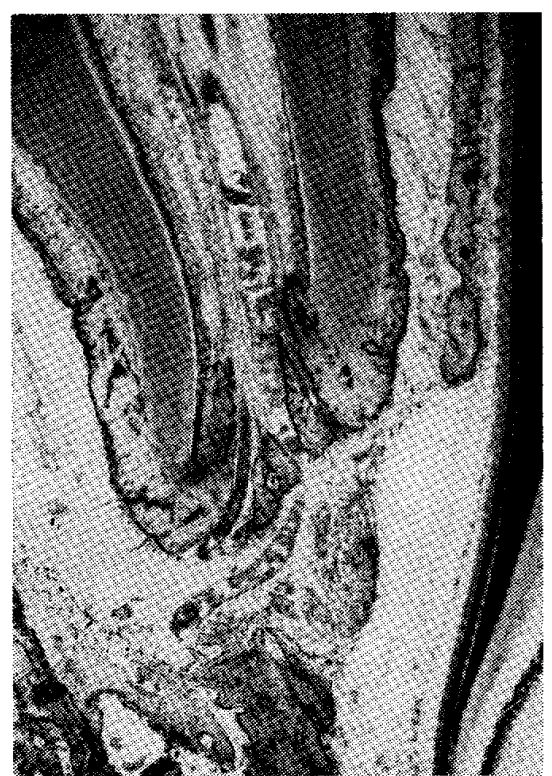

Fig. 3 Control

On the 14th day

H.E. Stain $\times 20$

術後 1 力月

この時期になると, 乳雬根の根尖部においては, 後継 永久歯歯胚の発育の影響により，明瞭な吸収像がみら れ, 乳霜根尖部有細胞セメント質, 象牙質が吸収され, その部に永久蒾蒾胚が近接している場合と, 全く乳歯根 の吸収像がみられない場合がある。乳雨雨根膜腔は 1 週 〜 2 週目の所見とほぼ同様で歯根膜線維束も規則正しく

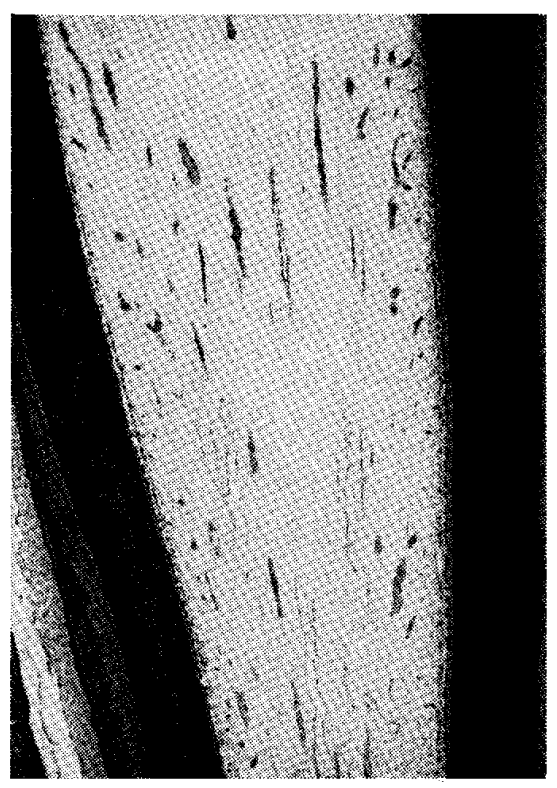

Fig. 4 Control

On the 1st month

H.E. Stain $\times 20$ 


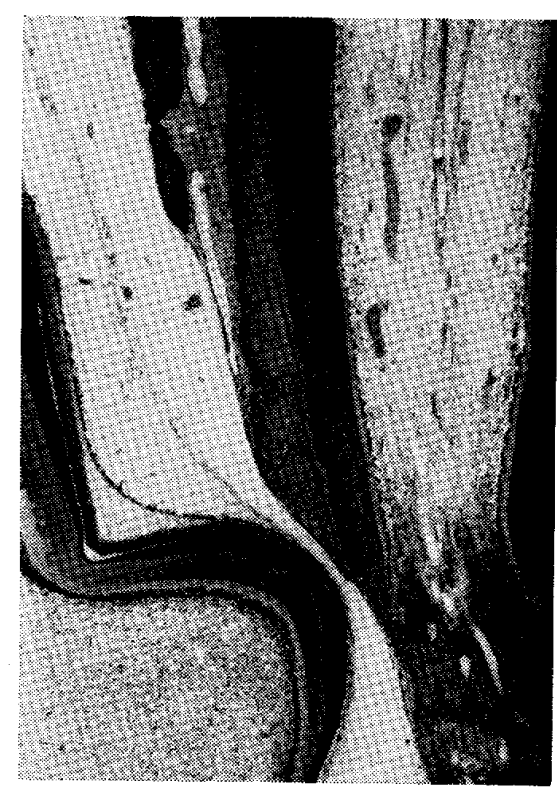

Fig. 5 Control

On the 1st month

H.E. Stain $\times 20$

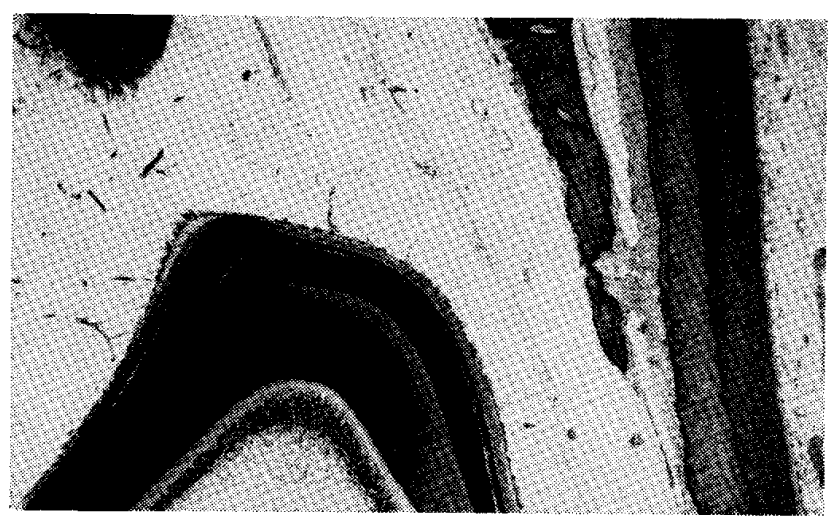

Fig. 6 Control

On the 1st month

H.E. Stain $\times 20$

機能的配列を示している．根尖の1/4 1/5の部では後継永 久歯の発育に伴って吸収像が垫められる。乳歯根の根尖 部セメント質の吸収部に近接した，後継永久歯歯胚の象 牙質は厚く形成され，エナメル質はこの時期に至っても 石灭化の不十分なエナメル質こして認められる。また内 エナメル上皮は順次, 細胞が長く伸びて円柱状のエナメ ル牙細胞に分化し，エナメル質の分泌を開始している所 見を示している.上皮鞘は伸長の時期にある．後継永久 歯の発育は第 3 乳臼柬直下の第 4 小曰曾に比べ第 2 乳臼 粜直下の第 3 小曰歯の発育が遅い.

この時期では未だ内外エナメル上皮細胞が認められる 場合が多く, 内エナメル上皮細胞, エナメル蹎および外
エナメル上皮細胞が合体して退化エナメル上皮として認

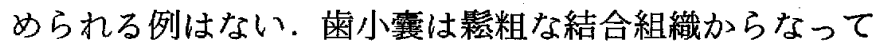
いる (Fig. 4, 5, 6).

術後 2 力月

この時期になると, 乳歯根の忣収過程は二つのパター ンに区別される.

一つは乳曾の根側セメント質, 象牙質の吸収が軽度に みられる場合である．乙の時期では，菌根膜腔はほぼ一 定の幅を保って抢り，柬根膜線維束も機能的配列を示 し, 線維芽細胞も豊富に認められるが，吸収部において は曾根膜線維束は離断され, 配列も不規則となり, 線維 芽細胞は減少している，蒾根膜に面した bundle bone は一部吸収像あるいは添加像がみられるほかは，一般に 平坦で骨面には骨芽細胞が整然と配列している（Fig. 7 ).

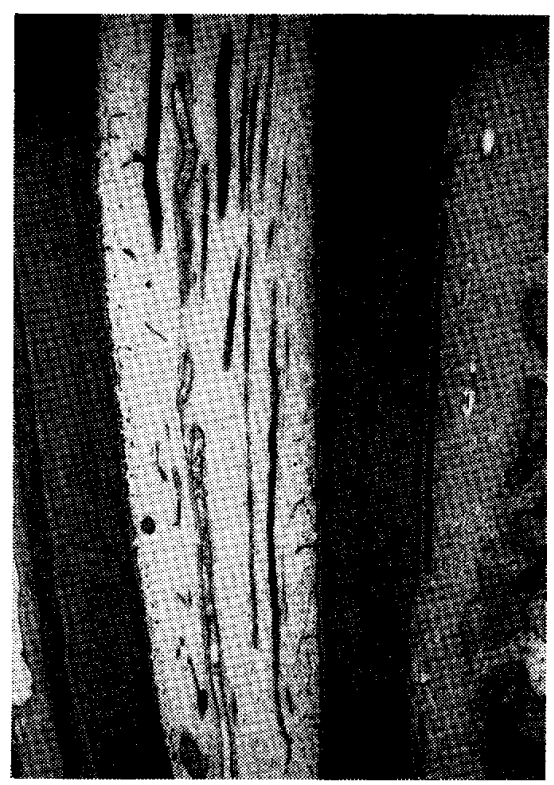

Fig. 7 Control

On the 2nd month

H.E. Stain $\times 20$

歯槽骨を介して後継永久粜歯胚が近接しているため永 久歯歯胚側の雬槽骨には多核の破骨細胞が著明で，大幅 な吸収像を呈している. 永久歯歯胚の発育は 1 力月目に 比べ順調に進行し, 歯冠部象牙質は厚く形成され, エナ メル質の形成も幅広く諗められ，標本上では石灰化が十 分であるため間隙となって白くぬけて認められる。一部 未石灰化の部分が存在し，その部はへマトキシリンに濃 染している. エナメル質形成部のエナメル器は扁平化し た退化エナメル上皮細胞となり，その外側には柬小囊が 存在している (Fig. 8). 


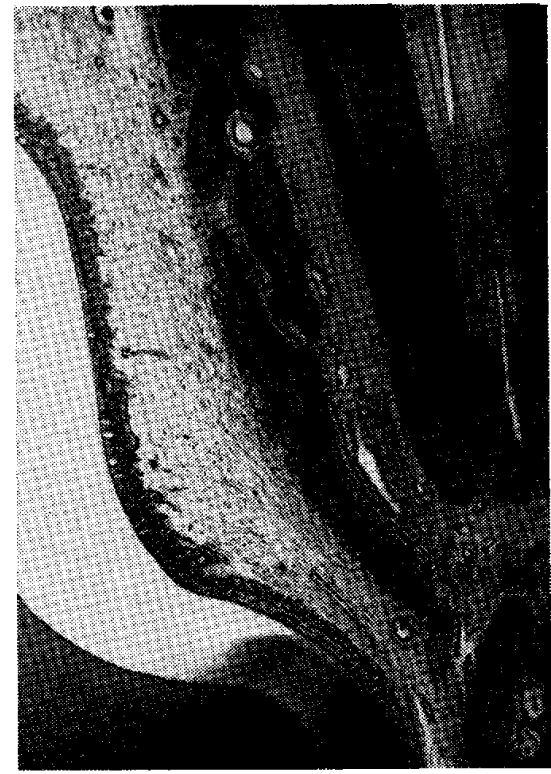

Fig. 8 Control

On the 2nd month

H.E. Stain $\times 20$

他の一つは乳雬根の吸収が根尖 $1 / 4$ 〜 1/5相当部で認めら れ，それ以外の歯根側には全く吸収像はみられない。歯 髄は血管の拡張, 允血が著明で, 僅かに細胞の減少がみ られる程度である．歯根膜線維束の配列は根尖の $1 / 4$ 〜 1/5 相当部までは未だ規則正しい配列を示しているが，歯根 膜に面した荬槽骨に大幅な吸収所見が認められる．乳歯 根尖部 $1 / 4 \sim 1 / 5$ 相当部の象牙質は吸収が著明で凹窝を形成 している. 吸収部が歯根膜と歯髄とを交通しているとて ろもある. 乳歯根尖部の歯根膜を一層介して後継永久囷 菌肧が近接している.エナメル質が形成され白くぬけた 部分や未だ石灰化の不十分な未石灰化の部分が存在して いる．エナメル器は退化エナメル上皮となり歯䯙を覆

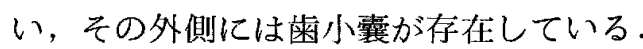

術後 3 力月

この時期になると後継永久㐘の萌出に伴い，歯小囊の 一部は压迫を受け，乳蒾根はほとんど吸収され消失して いる. 歯牙の吸収所見はさらに歯冠部まで進行し髅角付 近まで及んでいる，歯髄内には破骨細胞や血管が豊富 で, 組織球，好中球が多数観察され，吸収組織に置換さ れている(Fig，9)。

乳菊根の象牙質の吸収，消失した部には 4 5 個の多 核の巨細胞が並んで配列しているのが認められる．乳蒾 の雨頸部付近の菌根膜線維束は不規則な配列を示してい る.

後継永久歯歯肧は䨑頸部近くまで萌出し歯槽骨との間

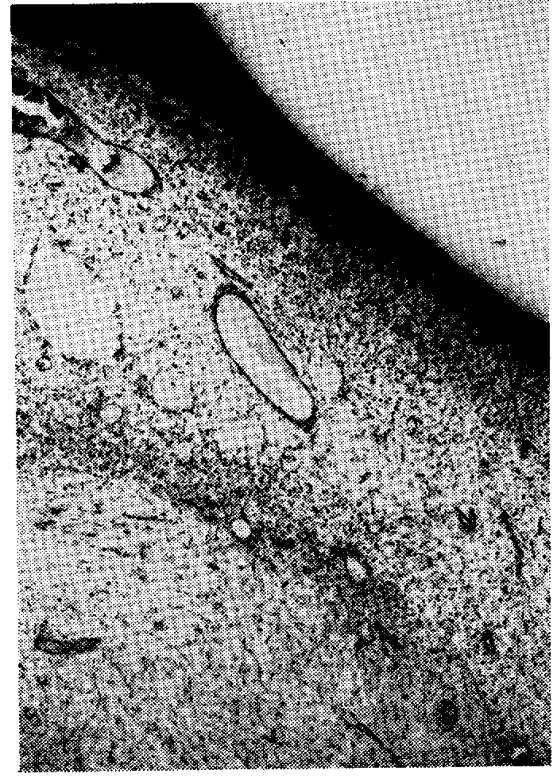

Fig. 9 Control

On the 3rd month

H.E. Stain $\times 20$

にはすでに菊根膜の形成が認められる．乳茵と永久歯と の交換期であることを物語って扔り，乳隶は脱落寸前に ある．エナメル質は退化エナメル上皮で囲まれ，その外 側には線維性結合組織が認められる（Fig.10，11）。ま たこの時期には永久歯の歯根も伸長している.

一般的には乳雬根はすべて吸収, 消失しており歯冠部 の髄角付近まで内部吸収を起している，歯髄は髄角部に

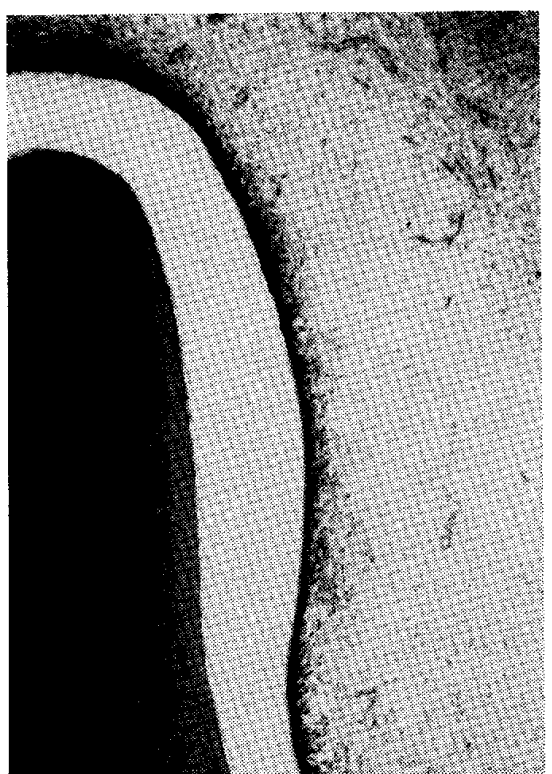

Fig. 10 Control

On the 3rd month

H.E. Stain $\times 20$ 


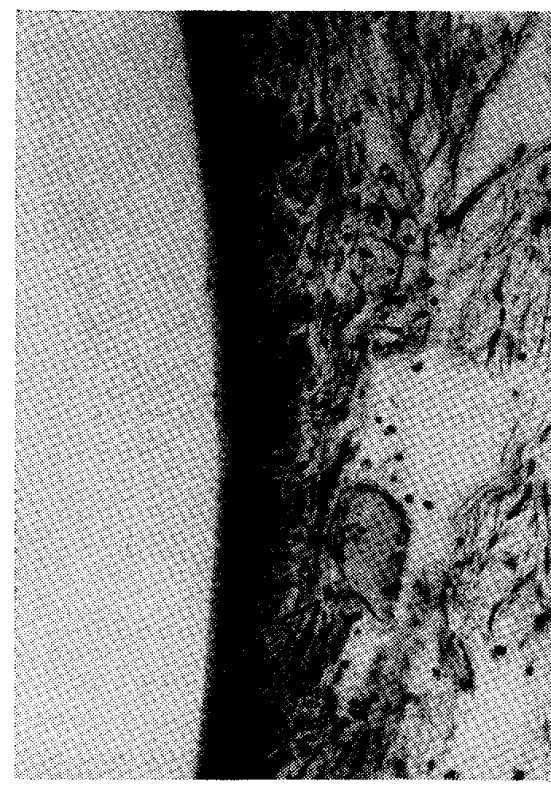

Fig. 11 A magnification of Fig. 10

H.E. Stain $\times 100$

微細血管が豊富に認められるのみで固有の雬髄組織はみ られず资症性の肉牙組織によって置換されている．後継 永久歯のエナメル質はすべて石灰化が十分で末石灰化な 部分は認められない，永久畨の萌出に伴い退化エナメル 上皮は口腔粘膜上皮と癒合するようになり，象牙質も厚 く形成され，霜根の長さも伸長するが，未だ末完成雬の 状態にあり，歯髄は幼若血管が豊富で，この時期は乳茵 と永久霜の交換期にある (Fig. 12). 根尖部には未だ Hertwig 上皮豧が認められる。

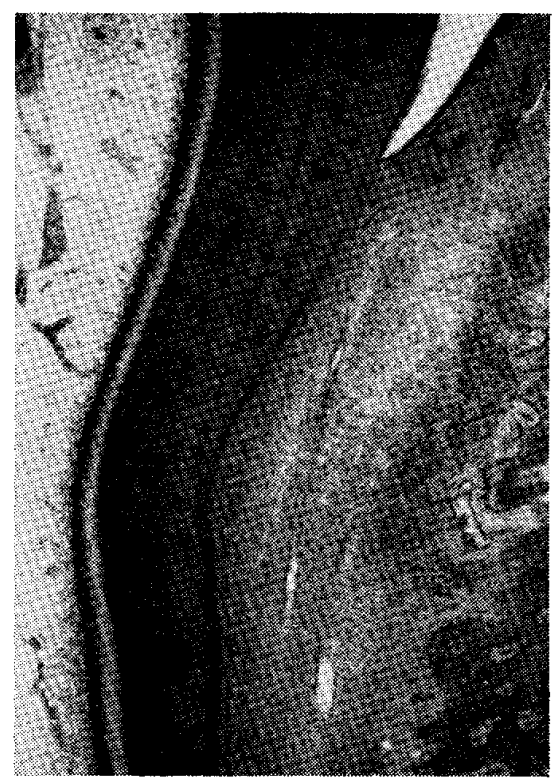

Fig. 12 On the 3rd month H.E. Stain $\times 20$

\section{II . 実験群}

Calvital

術後 1 週 2 週

乳歯根は一定の長さを呈し，根尖部は有細胞セメント 質により閉鎖されている。根管内は根尖部に至るまで抜 髄され一部根管充填材が残存している. 乳歯の歯根膜腔 は一定の幅を保って根尖まで連続している，歯根膜線維 には何ら異常はなく機能的配列を示し, 線維芽細胞も豐 富に認められる．㐘槽骨壁には骨牙細胞の規則正しい配

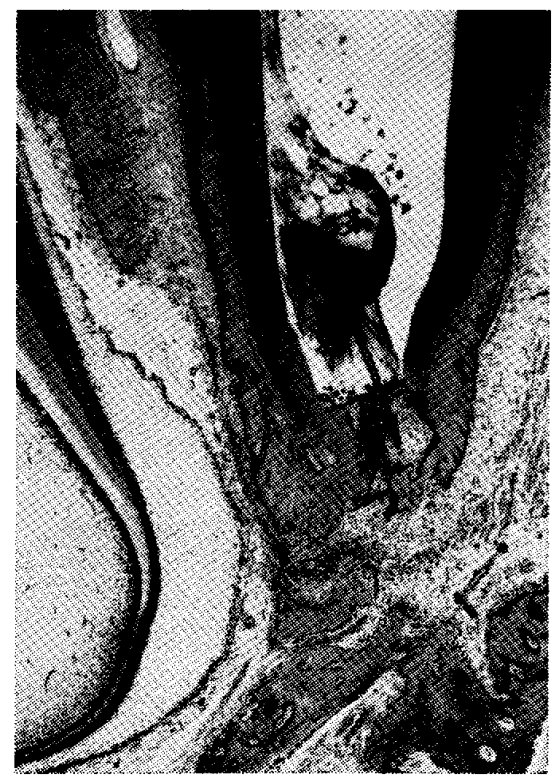

Fig. 13 Calvital

On the 7th day

H.E. Stain $\times 20$

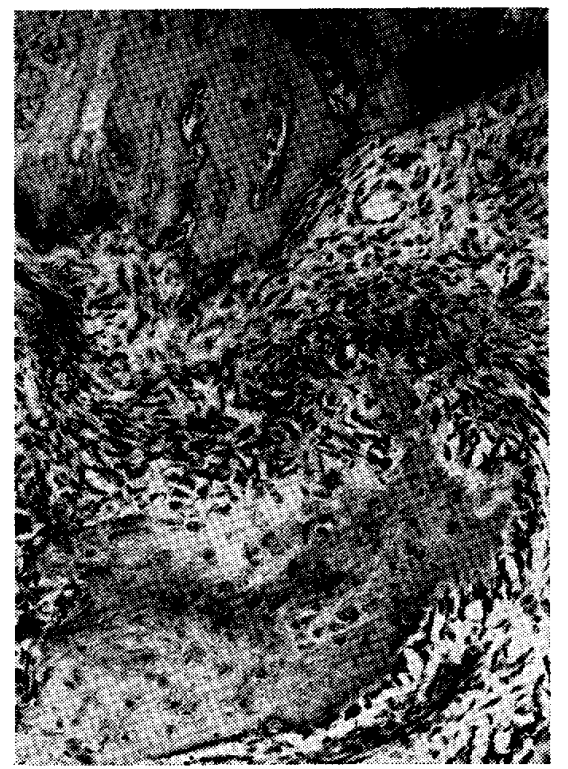

Fig. 14 A magnification of Fig. 13

H.E. Stain $\times 100$ 


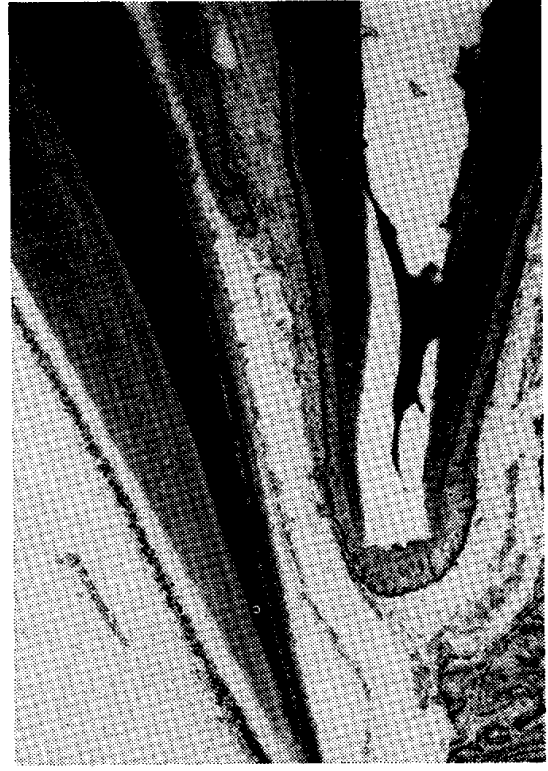

Fig. 15 Calvital

On the 14th day

H.E. Stain $\times 20$

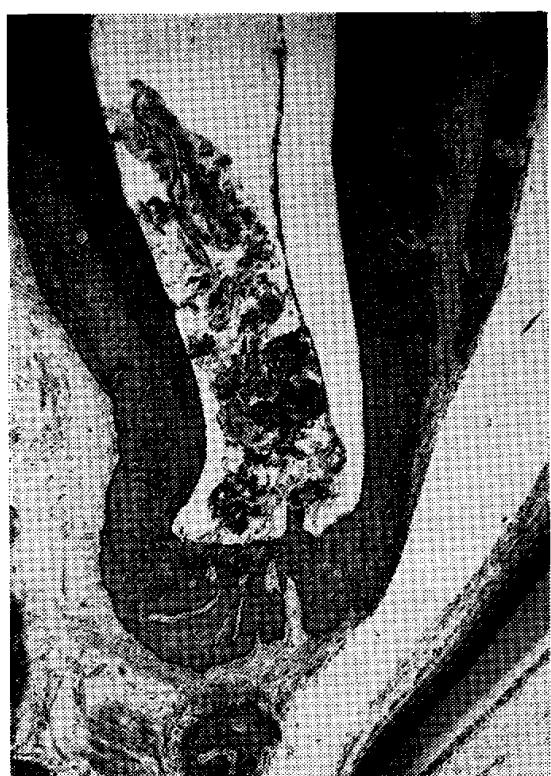

Fig. 16 Calvital

On the 1st month

H.E. Stain $\times 20$
列が認められる．乳歯根側には䨑槽骨を一層介して後継 永久歯歯胚が認められる．エナメル質は未石灭化の状態 にある。エナメル器は内エナメル上皮細胞, 中間層細胞, エナメル䯣，外エナメル上皮細胞抢よび霜小囊が明瞭に 認められる.乳菌根尖直下の菌根膜に軽度の線維芽細胞 の増殖がみられるほかは充填材料による歯根膜内の炎症 所見およびエナメル器の障害は誌められない(Fig. 13,

$14,15)$.

根尖部歯根膜に充填材料が浴出している症例では壊死 に陥っている所見や炎症性細胞浸潤は琵められないが， 充血調で出血策がみられる例もある，後継永久䨑歯胚の エナメル器に異常所見はみられない。

術後 1 力月

根管内は完全に抜䯣され充填材料が根尖部に一部残存 している. 乳蒾根には一般に吸収所見はみられないが根 尖部のセメント質に軽度の吸収所見がみられ，一層の歯 根膜 と雨小囊を介して後継永久霜霜胚が近接して認品ら れる. 永久歯歯胚は 1 週〜 2 週目に比へ歯冠部象牙質の 幅をやや増しているほかはエナメル質は未石灰化の状態 にあり，ヘマトキシリンに濃染している。エナメル器， 㐘小霅には何ら著変はみられない（Fig.16）。

根管内に充填材料や壊死組織が認められる例では根尖 直下の雬根膜組織には炎症性細胞浸潤はほとんどみるこ とがなく線維芽細胞の増殖により幼若な結合組織として 認められる。
術後 2 力月

乳蒾根は一定の長さを保ち，抜髄は根尖部まで行われ ている。一部根管側枝に組織の残存が認められるが壊死 に陥っている.乳茵根の吸収は柬根側から根尖部にかけ て認められない，乳霜の茵根膜線維束は斜走し規則正し い配列を示し 線維芽細胞の豊富な所見として認められ る。骨壁はほぼ平坦な面を呈している，乳菌根舌側下方 の後継永久歯歯胚が近接している部においては骨は吸収 消失して抢り歯根膜を一層残すのみとなっている．根尖 歯根膜の一部に空胞化が認められている，永久蒾歯胚の 象牙質は厚く形成されエナメル質形成部とエナメル質の 未不灰化部とが混在して認められる.エナメル器はエナ メル芽細胞，中間層細胞，エナメル髄が合体して立方状 の退化エナメル上皮細胞として認められ，その外側には 歯小敕が存在し何ら著変はみられない（Fig．17）。乳菌 の吸収は篓根側の外部吸収は誌められないが，根尖の $1 / 4$ 〜1/5相当部にセメント質の吸収がみられる例では，その 部に僅かにみられる柬根膜組織は吸収組織に置換されて いる．乳霜根尖部付近のエナメル質は石灰化不十分で未 脱灭標本としてみられ，規則正しいエナメル小柱が認め られる.内外エナメル上皮細胞は合体して退化エナメル 上皮となり扁平化した細胞により形成されている．乳歯 雪根側の部では咬頭頂の部のエナメル質は石灰化は十分 で標本では白く外認められる．後継永久蒾歯胚の菌 頸部付近のエナメル質は未石灰化の状態を呈しているの 


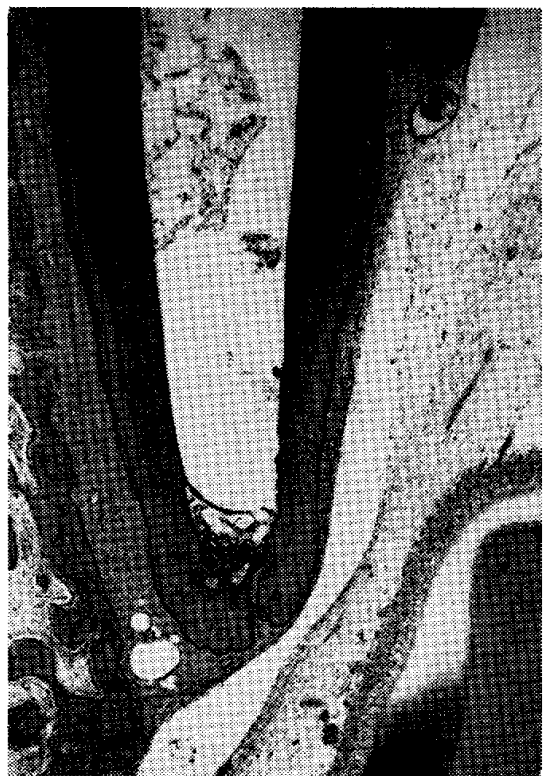

Fig. 17 Calvital

On the 2nd month

H.E. Stain $\times 20$

に，乳雬根側の外部吸収が認められる例がある。

術後 3 力月

根管队には充搷材料が残存している，歯根の $\frac{1}{2}$ 付近ま で乳柬根の吸収がみられ，歯根膜側からの外部吸収によ りセメント質, 象牙質は吸収され凹窩を形成している部 分と, セメン卜質, 象牙質が吸収され, その部に多核の 巨細胞が並んで浔められる.乳蒾根 $1 / 2$ 吸収部には後継永 久㐘が近接し，咬頭頂が位置し，その部のエナメル質は 雨頸部に至るまで石灰化が十分で退化エナメル上皮とな り，霜根膜は吸収組織に置換されている（Fig．18）。 た歯頸部付近に至ると新たな歯根膜組織の再生が活発に 行われ, 線維芽細胞が豊富に認められる。永久歯根側の 結合組織内には骨梁の形成がみられ, 表面には骨芽細胞 の增殖が著明となっている。

また乳柬根の $1 / 2$ 付近に永久歯の咬頭頂が位置し，その 部分の菡根の外部吸収のみがみられ, その他の䨑根吸収 が遅延している例も認められる.いずれにしても歯髅内 部からの吸収がないる後継永久霜の萌出による歯根の 吸収は対照群に比べ明らかに遅延してみられる。すべて の例において炎症所見はほとんどなく後継永久蒾の萌出 にあたって炎症による障害はほとんどみられないが対照 群にみられるようなスムーズな㐘根吸収は行われてい ない．乙の時期になると乳茵と後継永久柬との交換が 行われる寸前にあるため永久菌の苗根の形成も伸長し Hertwig .上皮鞘も下方に向って伸びている．㐘根膜腔

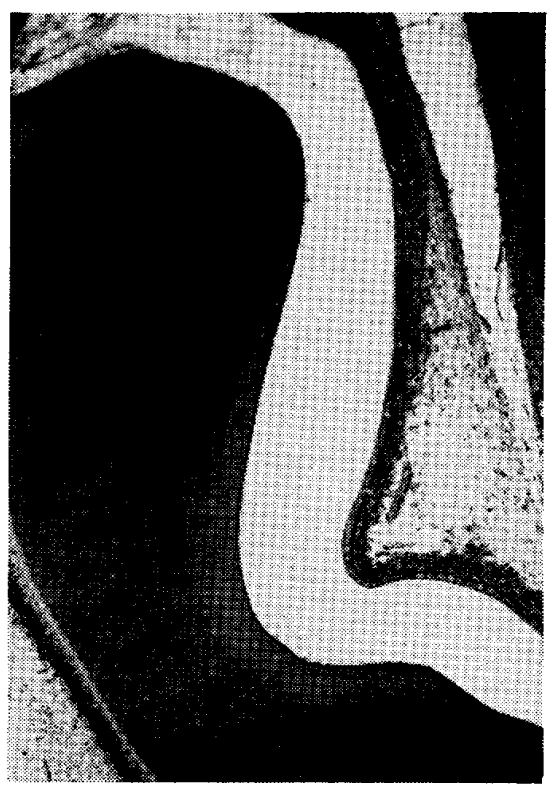

Fig. 18 Calvital

On the 3rd month

H.E. Stain $\times 20$

は幅を広くし，再生した歯根膜線維束もみられるが太く 走行は未だ不規則である．新生骨梁に比べ結合組織が多 く, 骨面には骨车細胞の増殖が著明で, 霜根膜に面した 骨には未だ bundle bone の形成はみられない。

\section{Vitapex}

術後 1 週 2 週

乳蒾根の長さは一定に達し，根尖部は開鎖されてい る。乳茵柬根膜線維束はほぼ規則正しい配列を示してい る. 乳霜根と後継永久畨歯胚の間には骨が介在してい る。㐘髄は根尖部に至るまで抜髄されている。しかし Fig. 19，20では根尖部蒾髄は僅かに残存し，歯髄組織 は変性，萎縮がみられ買死飞陷っている．根尖直下の歯 根膜は軽度の限局した炎症性細胞浸潤ならびに大小の空 胞形成がみられ，幼若な結合組織で満たされる．歯槽骨 を介して後継永久電䨑胚が存在し, 丈の低い立方状のエ ナメル芽細胞, 星状網がみられ, 丈の高い円柱状のエナ メル芽細胞に移行し, 歯冠部に向かう未石灰化のエナメ ル質部で星状網は消失している。

乳崡の根管内は根尖に至るまで抜髄されているが根尖 部付近には根充材の残存が認められる．根充材が根尖歯 根膜に溢出している例では根充材を取り囲むようにその 周囲柬根膜に石灰化組織の形成がみられる，根尖周囲歯 根膜内には大小の空胞形成, 出血巣がみられ, 軽度の細 胞浸潤がみられるほかは幼渃な結合組織としてみられ る. 歯胚には何ら炎症所見はみられず，広く形成された 


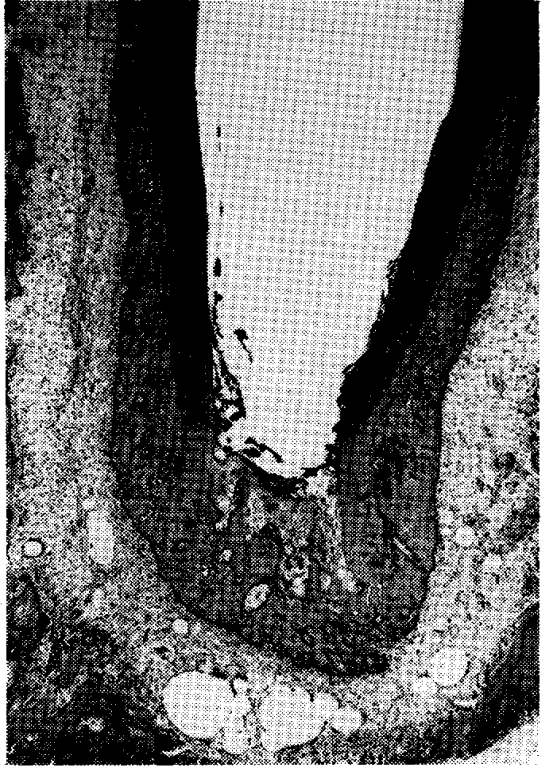

Fig. 19 Vitapex

On the 7 th day

H.E. Stain $\times 20$

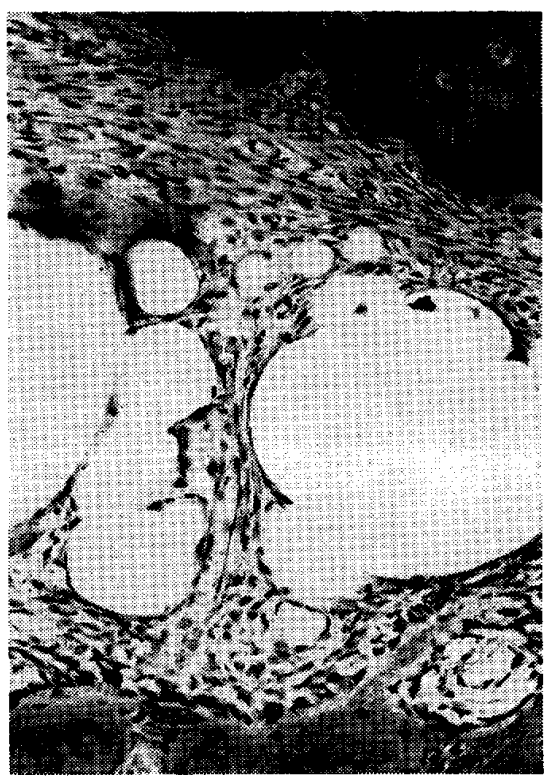

Fig. 20 A magnification of Fig. 19 H.E. Stain $\times 100$

象牙質に接して未不灰化のエナメル質の形成がみられ， その外側には歯小囊が明瞭である（Fig. 21，22）.

術後 1 力月

乳崡根管内は根尖に至るまで抜髄されており，根管内 には菲薄な根充材の残存がみられる。乳歯根は歯根側, 根尖部で一部吸収所見がみられる、根尖部セメント質, 象牙質の一部は吸収され根尖直下の曾根膜内に根充材の 浚出した所がみられる. 充填材周囲の歯根膜内には軽度

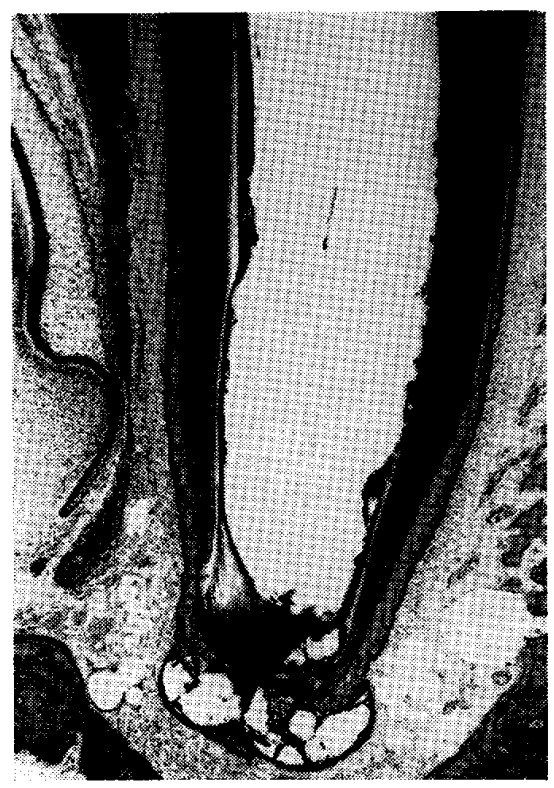

Fig. 21 Vita pex

On the 14th day

H.E. Stain $\times 20$

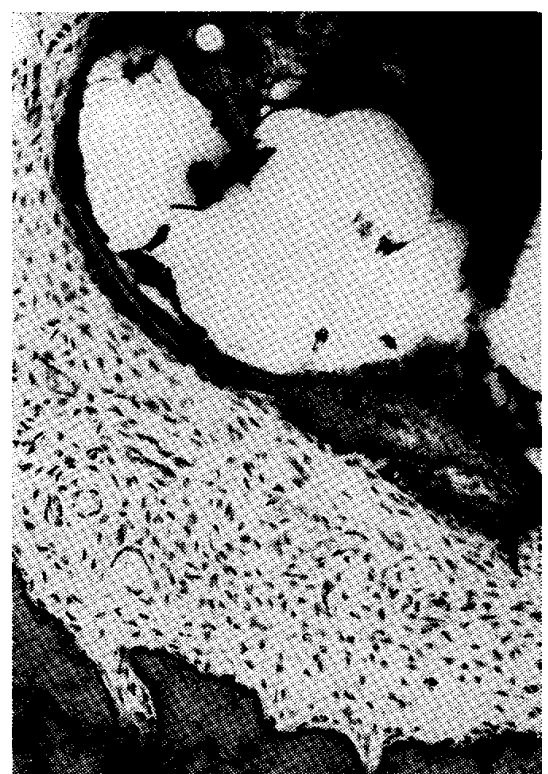

Fig. 22 A magnification of Fig. 21 H.E. Stain $\times 100$

の炎症性細胞浸潤と多数の空胞形成が認められる．乳㐘 根の両側からは後継永久歯蒾胚が近接している.エナメ ル質は未石灰化の状態にあり炎症部位から離れたエナメ ル質には何ら異常所芫はみられないが，根尖蒌根膜を一 層残して根尖歯根膜の炎症巣に近接した部ではエナメル 芽細胞，中間層細胞，外エナメル上皮細胞は扁平化，融 合，融解像を示し，細胞の配列が不規則である．外側の 菊小霉の部では空隙として認められる（Fig. 23）。 


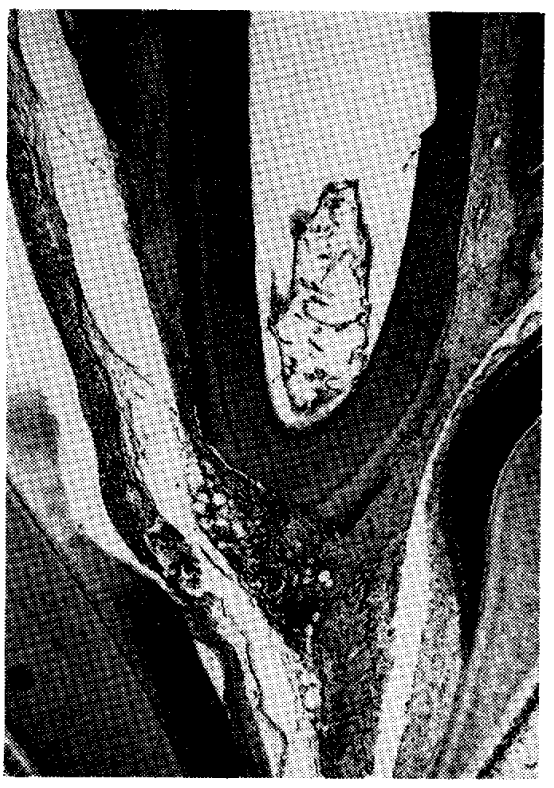

Fig. 23 Vitapex

On the 1st month

H.E. Stain $\times 20$

一般にこの時期では乳荬根には根側の外部吸収はな く，根尖部に僅かな吸収がみられる程度である。根尖部 直下の㐘根膜内には好中球, リンパ球, 多形核白血球な ど炎症性細胞浸潤や大小の空胞形成がみられるが，歯根 膜は幼若な結合組織としてみられる。炎症が㕕範囲にな るとエナメル器の細胞に変化を起し, 変性, 消失などの 所見が認められる。

術後 2 力月

乳霜は後継永久歯崡胚が近接している部では雪根膜を 一層残すのみである。乳歯根は一部蒾根膜側から軽度の 外部吸収がみられる場合と Fig. 24,25 亿示すよう根 尖に至るまで全く吸収所胃がみられない場合がある，歯 骨道は根尖部まで完全に抜髄されている。根尖直下の蒾根 膜組織には限局して大小の多数の空胞形成が認められ健 全な雬根膜はみることはできない。しかし周囲には炎症 性細胞浸潤は認められない，蒾槽骨には何ら炎症所見は みられず歯根膜に面した bundle bone も平坦で，骨壁 には骨芽細胞が規則正しい配列を示している，歯根膜腔 も一定の幅を保ち，歯根膜線維束も機能的配列を示し， 線維芽細胞も密に配列している，歯根側に歯胚が近接し ている部では歯根膜の一部に空胞形成がみられる。

粜根膜に接した星状網の一部に空胞形成が波及してい る。炎症所見はみられない。エナメル質は咬頭頂付近で は石灭化は十分でェナメル牙細胞, 中間層細胞で占めら れ円柱状あるいは丈の低い細胞が認められる．また立方

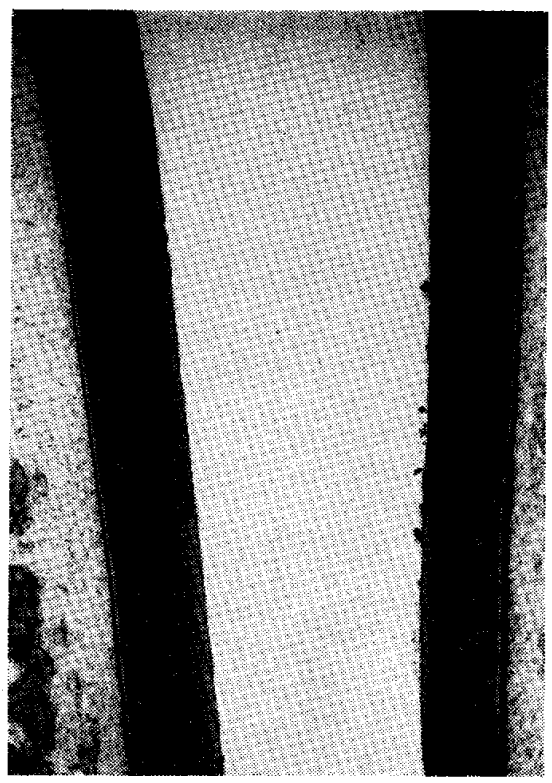

Fig. 24 Vitapex

On the 2nd month

H.E. Stain $\times 20$

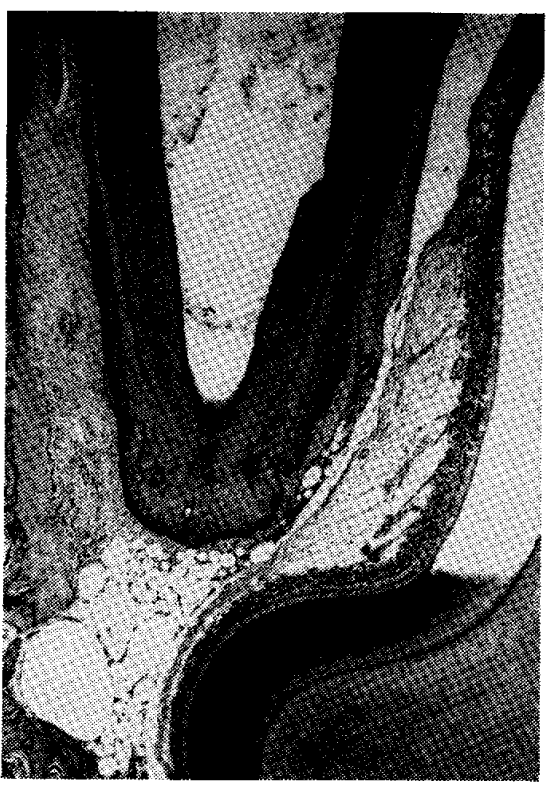

Fig. 25 Vitapex

On the 2nd month

H.E. Stain $\times 20$

状の緗胞も配列しており，外エナメル上皮に移行してお り退化エナメル上皮としてみられる．また立方状の細胞 む配列しており外エナメル上皮に移行しており退化エナ メル上皮としてみられる。歯頸部に至る部では未石灰化 の部分が認められ，低円柱状を呈した細胞によりなって いる (Fig. 24). 
菌根側に外部收収がみられる例では Fig 26 亿示すよ うに，セメント質，象牙質吸収部までセメント質様硬組 織の添加と歯槽骨の増列值により骨様硬組織の侵入が認め られ，そのため歯根膜線維束は離断され配列も不規則と なり, 吸収細胞の出現や咨症性細胞浸潤が認められる。 このように骨性癒着の症例では永久蒾の萌出は遅れてい る。

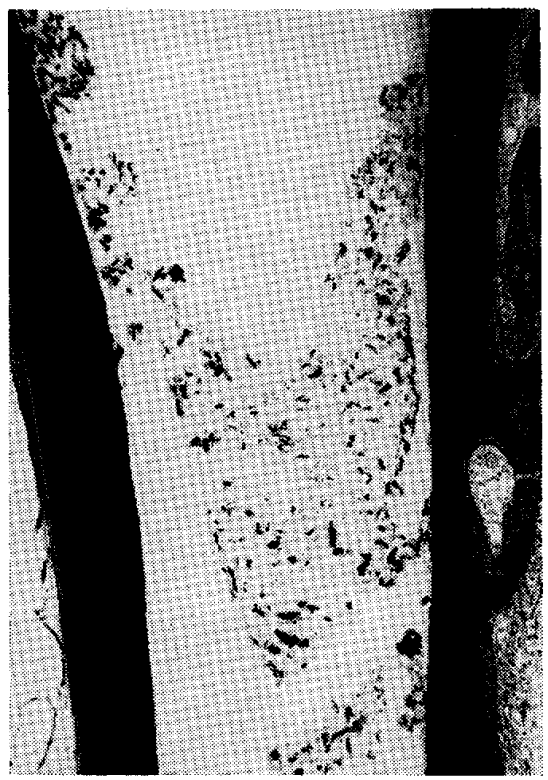

Fig. 26 Vitapex

On the 2nd month

H.E. Stain $\times 20$

術後 3 力月

この時期になると柬根吸収は進み，永久㐘の咬頭頂は 歯根側に沿って近接し萌出寸前にあるものの柬根吸収は 根尖部より歯根側に向って平等に吸収されるのではなく 永久歯の近接している部において吸収の進行速度が速い が他の部位では未だ菌根吸収は遅延している．外部吸収 部の歯根膜組織には強い炎症栄がみられ永久歯の近接に 伴い吸収組織に置換され，リンパ球，好中球を主とする 炎症性細胞浸潤が強く,退化エナメル上皮細胞に波及し， 变性を菱起し融解像も認められる（Fig. 27，28）。

\section{Kri I}

術後 1 週 2 週

乳歯雨根膜は一定の幅を保ち霜根膜線維束も規則正し い配列を示している.根尖歯髄は僅かに残存し,その部に 好中球の浸潤がみられるが線維成分の豊富な所見を示し ている.根尖直下の歯根膜にも好中球,マクロファージの 出現がみられる，後継永久雪曾胚は外側に扁平な外エナ メル上皮細胞が配列し，内側に星状細胞からなるエナメ

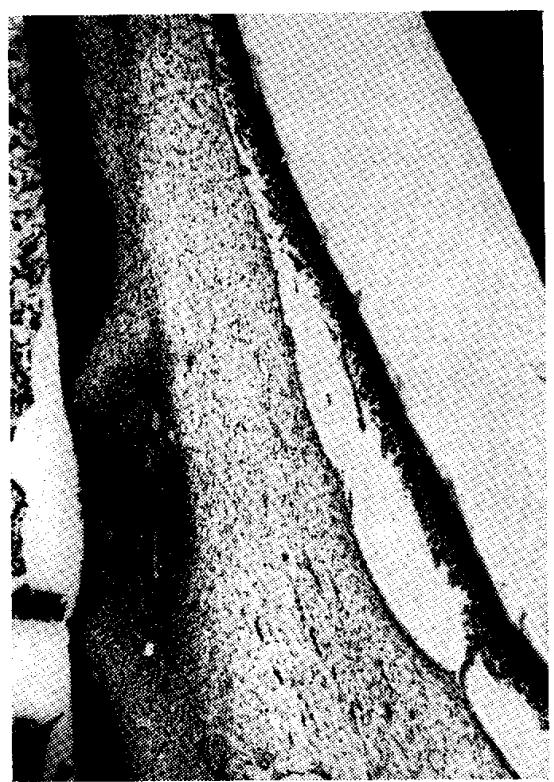

Fig. 27 Vitapex

On the 3rd month

H.E. Stain $\times 20$

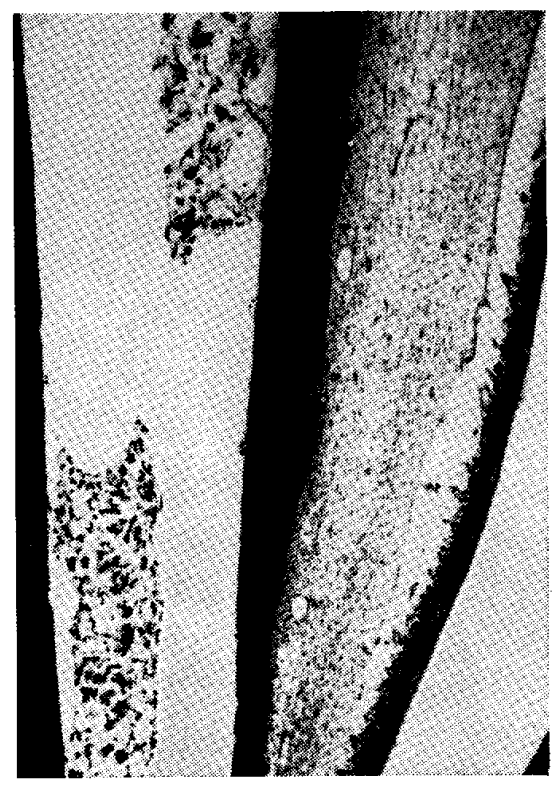

Fig. 28 Vitapex

On the 3rd month

H.E. Stain $\times 20$

ル髄がみられ，さらに高円柱状のエナメル芽細胞との間 に一，二層の扁平な細胞の重なった中間層がみられる。 エナメル器には何ら異常所見はみられない（Fig．29）.

乳歯根は歯槽骨によって囲まれ一定の長さに達してい るが，末だ根尖部は開大し未完成の状態にある。根管は 根尖に至るまで抜揈され充媜材が僅かに散見される。根 尖歯根膜ならびに周囲組織は広範囲にわたってリンパ 


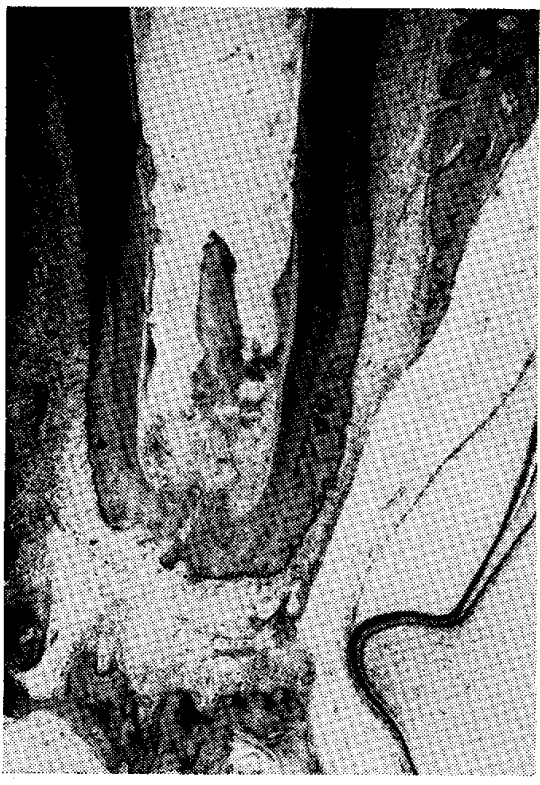

Fig. 29 Kri I

On the 7 th day

H.E. Stain $\times 20$

球，好中球，形質細胞などの炎症性細胞がびまん性に浸 潤している。その外側は炎症性の肉芽組織が認められ

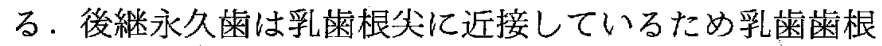
膜の炎症は霜胚にまで及んでおり同部の外エナメル上皮 細胞は消失，エナメル髄の星状細胞が僅かに残存してい る程度である，直下のエナメル牙細胞は一部消失し一部 は円柱を示さず不規則な形をとっている．また乳歯根尖

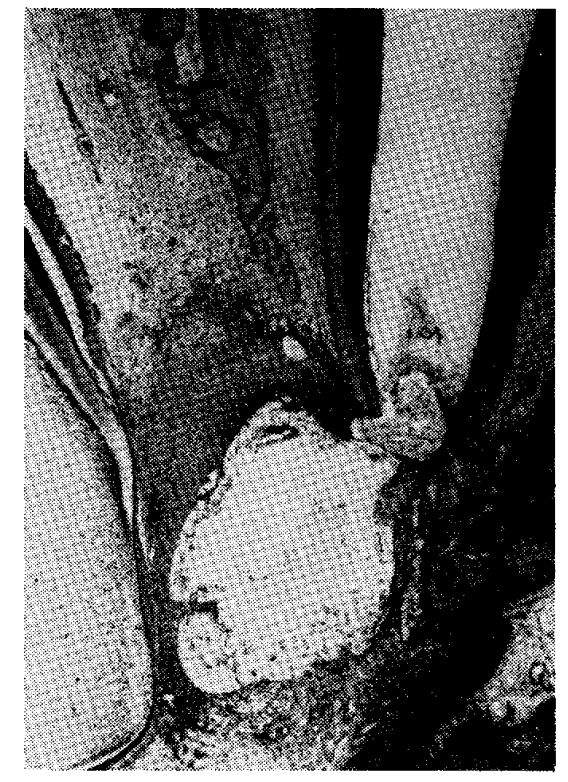

Fig. 30 Kri I

On the 7 th day

H.E. Stain $\times 20$

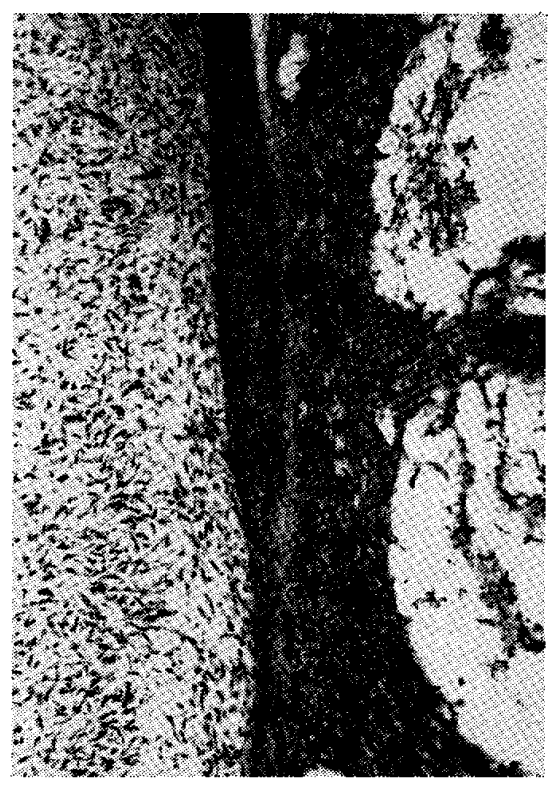

Fig. 31 A magnification of Fig. 30

H.E. Stain $\times 100$

部の一部には吸収細胞がみられ病的吸収が諗められる。 炎症巣周囲の内エナメル上皮細胞は不定形を呈し, 数風 の重なった所見としてみられる（Fig. 30，31）。

乳霜根は一定の長さに達し, 根尖部はセメント質によ って閉鎖されている．根管内の米髄は完全に抜髄されて いる，根尖直下の歯根膜は好中球，マクロファージから なる炎症性の肉芽組織の増殖がみられ，その周囲は線維 性結合組織によって囲まれている，線維性結合組織内に

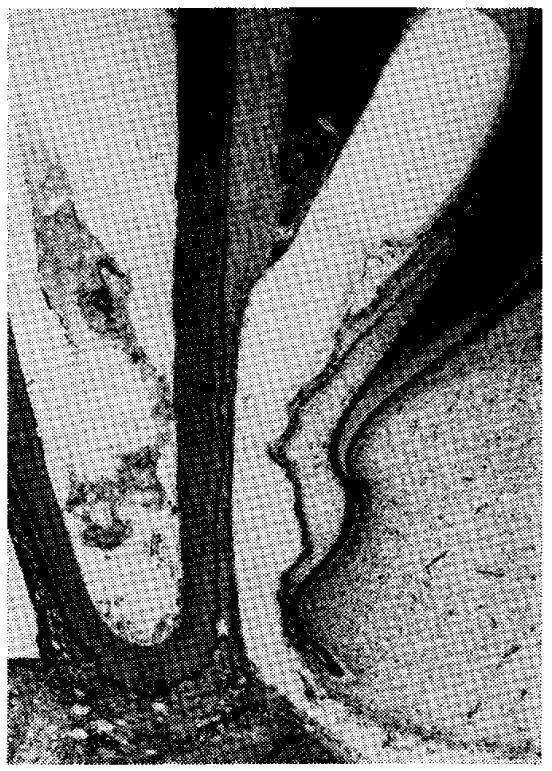

Fig. 32 Kri I

On the 14th day

H.E. Stain $\times 20$ 


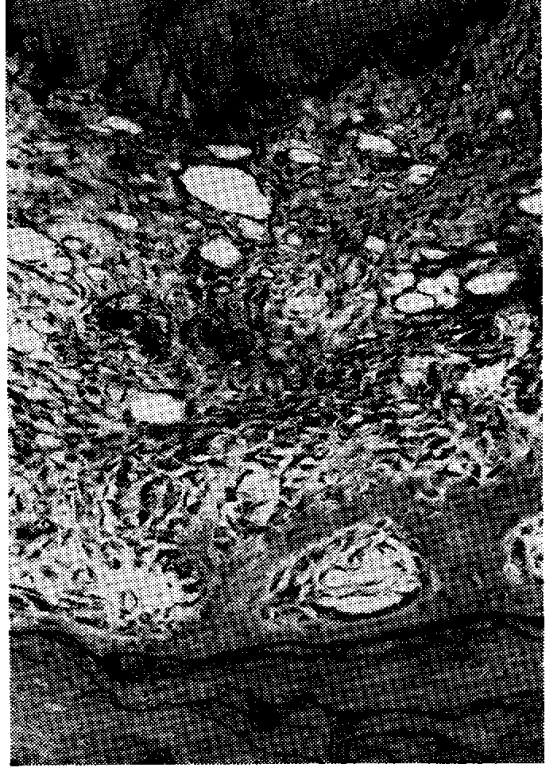

Fig. 33 A magnification of Fig. 32 H.E. Stain $\times 100$

は多数の空胞がみられる，根尖部セメント質には吸収細 胞がみられ吸収所見がみられる。根尖直下の菊槽骨には 骨細胞を含む菲薄な新生骨梁の形成が認められる，歯肧 には外エナメル上皮細胞の部に萎縮, 配列不整がみられ るほかは正常像を呈している（Fig．32，33）。

\section{術後 1 力月}

一般にての時期に至っても乳友根の根側は歯根膜側か らの外部吸収はみられないが，Fig. 34 に示すように根

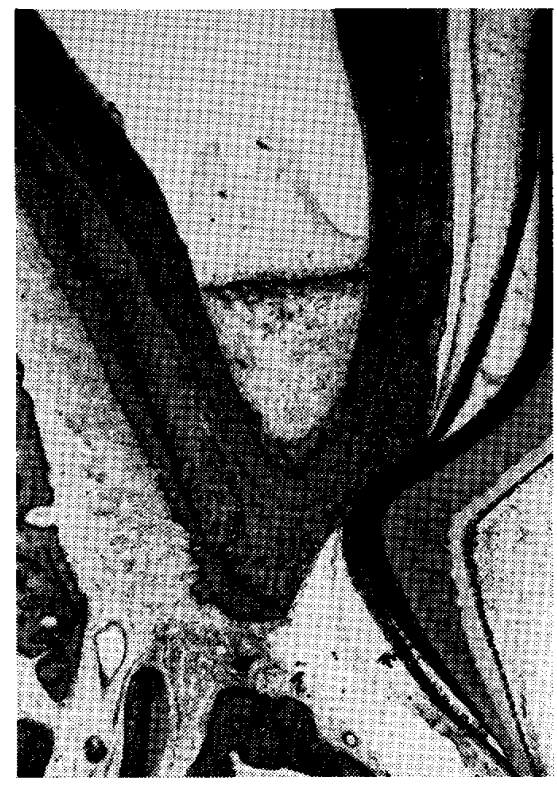

Fig. 34 Kri I

On the 1st month H.E. Stain $\times 20$
尖部に後継永久歯菌胚が直接接しその部のセメント質の 吸収がみられる例がある。歯胚の接していない部の歯槽 骨，爾根膜には何ら著変はみられない，根管荗髄は完全

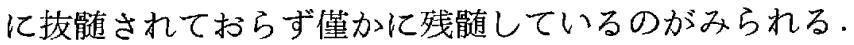
その部では好中球の浸潤と線維牙細胞からなる肉芽組織 の所見を呈している．根尖直下の歯根膜は線維来細胞の 増殖がみられ幼若な結合組織所見を呈している，崡胚が 乳霖根を圧迫しているためその部のセメント質は吸収さ れ, 歯胚についてみるとエナメル芽細胞, 中間㐿細胞, 外エナメル芽細胞は扁平化, 萎縮を呈している.

Fig. 35，36 に示しているょうに乳菌根側の歯根膜, 蒾槽骨に何ら著変はみられない，根尖部に至ると残鹃が

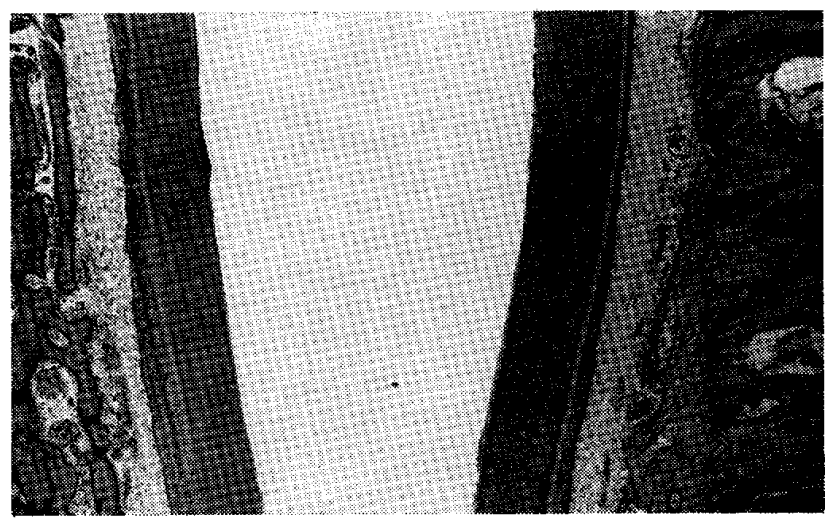

Fig. 35 Kri I

On the 1st month

H.E. Stain $\times 20$

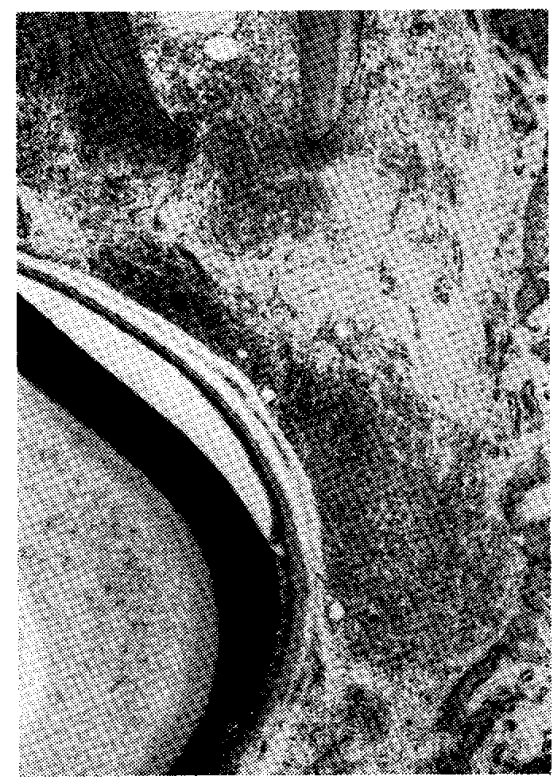

Fig. 36 Kri I

On the 1st month

H.E. Stain $\times 20$ 
みられ根尖直下の歯根膜から周囲組織の広範囲にわたっ て好中球, リンパ球, マクロファージなどの炎症性細胞 浸潤がびまん性に認められる。

直下に存在している歯胚のエナメル牙細胞は配列の乱 れがあり，中間層細胞は肥厚しエナメル髄は消失してい る。

\section{術後 2 力月}

乳䨑根管歯髄は根尖部に至るまで完全に抜㵦されてい

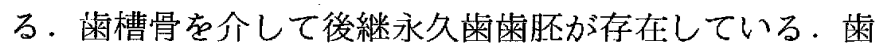
根側上部に扔いては部分的に Fig. 37,38 亿示すよう に薄い一層を形成しているセメント質の吸収がみられ， さらに象牙質まで波及しているため象牙質は凹窝を形成 している. 吸収窩には破骨細胞がみられ，ての部の雪根 膜には好中球, マクロファージ, リンパ球, 形質細胞な ぞの炎症性細胞浸潤が諗められる。歯根膜線維束の配列 は不規則となり減少し, 炎症巣周囲の菌根膜には線維芽 細胞の増殖が著明である. 歯槽骨においても歯根膜に面 した炎症巣の部において吸収所見が認められる。

後継永久歯歯胨は咬頭頂から歯頸部付近まではエナメ ル質の石灭化は十分であるが歯頸部から基底部に至る部 分では未石灰化としてェナメル小柱の存在がみられる. 乳歯根尖部直下の咪根膜は好中球, マクロファージ,リ ンパ球，形質細胞などの炎症性細胞浸潤が波及している ため, 近接した後継永久霜歯胚のエナメル質未石灰化部 分に扔いては, 星状網, 外エナメル上皮は破壊され中間 層付近まで炎症が波及している．そのためエナメル質の

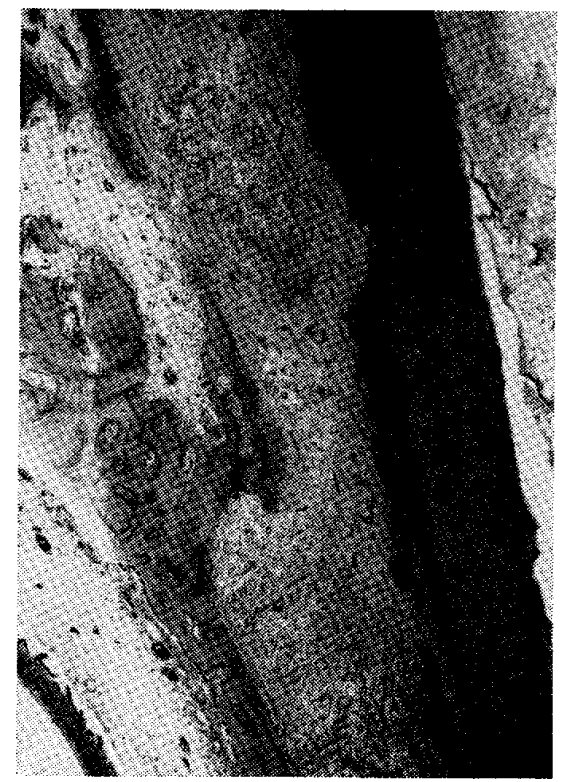

Fig. 37 Kri I

On the 2nd month

H.E. Stain $\times 20$

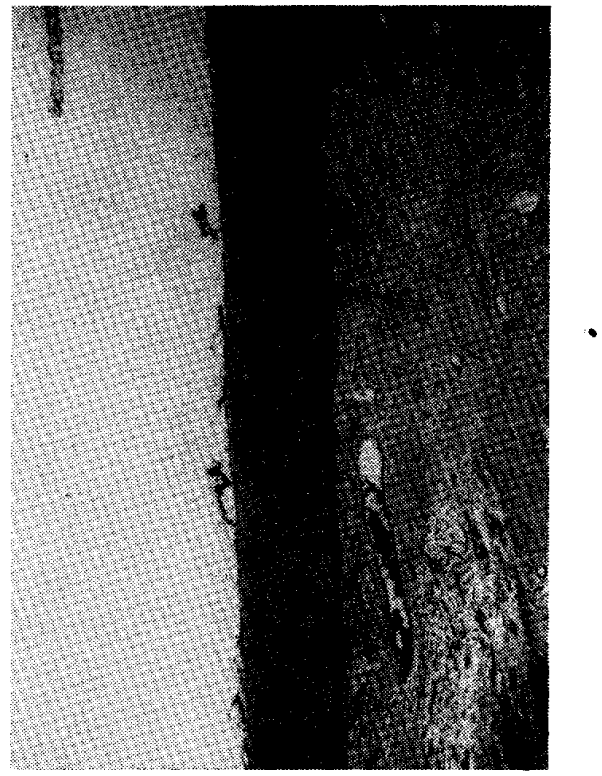

Fig. 38 Kri I

On the 2nd month

H.E. Stain $\times 20$

一部に形成不全が認められる.

術後 3 力月

乳粜根は根側, 根尖側ともに吸収が著しいものの未だ 幅広い歯根象牙質がそのまま残存している所もみられ る. 乳歯根に隣接して萌出する後継永久蒾の咬頭頂は蒾 頸線_ヒにあり，すでに萌出を開始している（Fig．39）。 永久歯の菌根の発育も進行し, 柬頸部を被覆する口腔粘

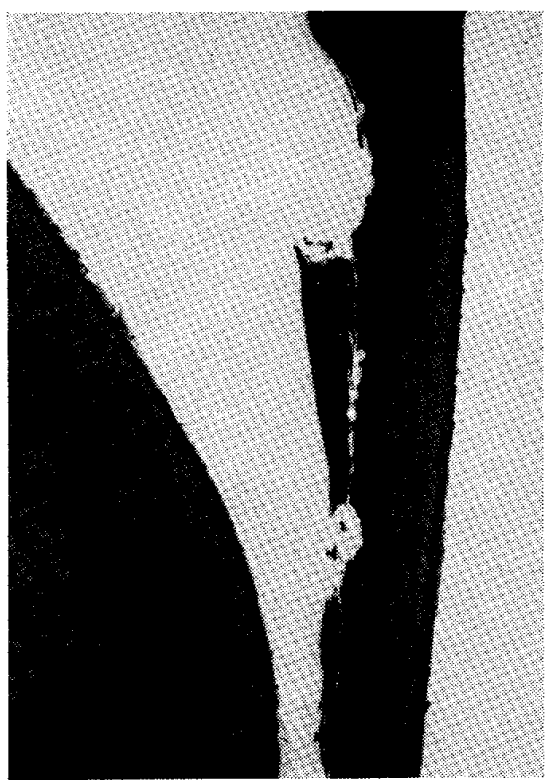

Fig. 39 Kri I

On the 3rd month

H.E. Stain $\times 20$ 
膜上皮の新生がみられ，歯根膜には線維芽細胞が密にみ られ新生血管が䔲富である（Fig．40）。柬根膜腔は幅厇

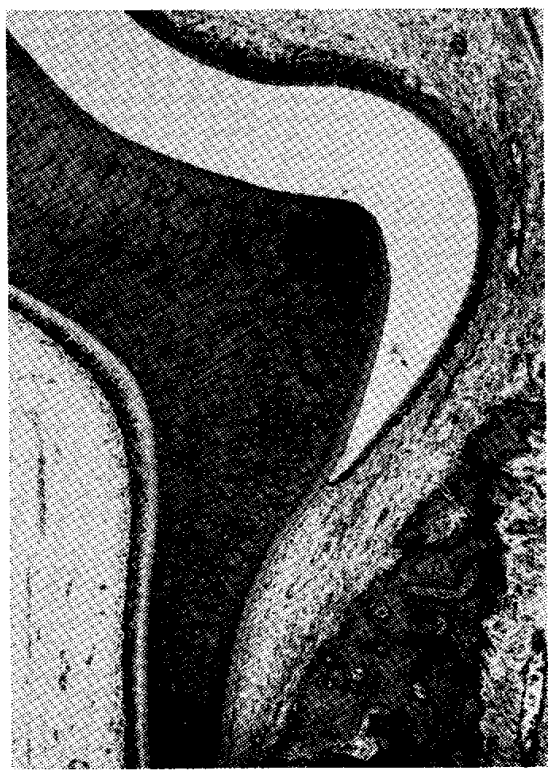

Fig. 40 Kri I

On the 3rd month

$H$ E. Stain $\times 20$

く骨の改造がみられ造骨細胞が軖富であるままた一方萌 出中にある永久柬の咬頭頂付近のエナメル質は石灰化が 完全に行われ白くぬけ，その表面には退化エナメル上皮 が認められ，口腔粘膜上皮と癒合するようになる。

乳憐根尖菌根膜から萪槽骨にかけて広範国な好中球， リンパ球，マクロファージなどの炎症性:紐胞浸潤がみら れ，その外側には線維牙細胞の増殖がみられ㭃若な結合 組織として䜑められる。炎症の範囲は退化エナメル上皮 にまで及び扁平化ならびに菱縮がみられる。

\section{Neodyne}

術後 1 週 2 週

乳歯根は一定の長さに達し，根管歯䯙は完全に圾髄さ れ韭薄な充填材の残存が認められる。歯根は雪槽骨によ って囲まれその外側には歯小囊がるられ後継永久柬柬肧 が隣接している.柬肧の蒾冠部のエナメル質は未石灰化 の状態にあり外エナメル上皮細胞が消失している部では エナメル芽細胞は丈の高い円柱状を呈し，中間層細胞， エナメル髄, 多エナメル上皮細胞がみられる部ではエナ メル牙細胞は丈の低い立方形を呈している（Fig．41）. 乳歯根尖直下の柬根膜に叁範囲にわたってリンパ球, 形 質細胞を主体とした炎症性細胞浸潤が認められ，雪槽骨 周囲にまで及んでいるのがみられる(Fig．42).

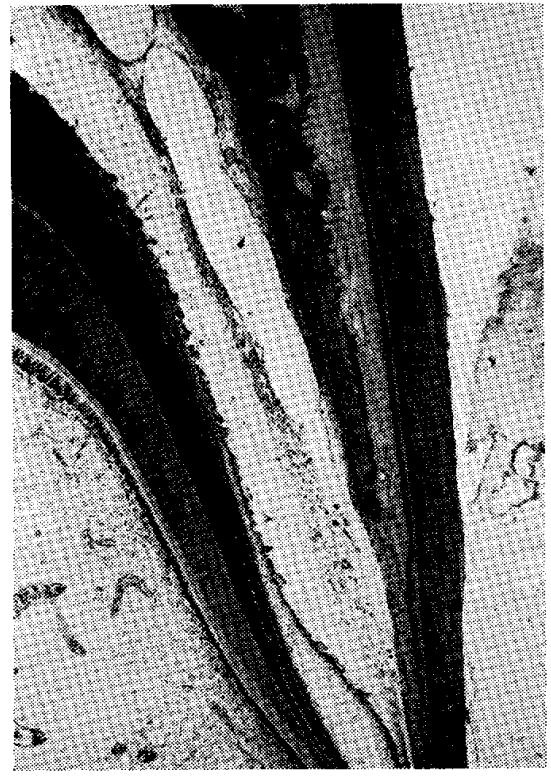

Fig. 41 Neodyne

On the 7 th day

H.E. Stain $\times 20$

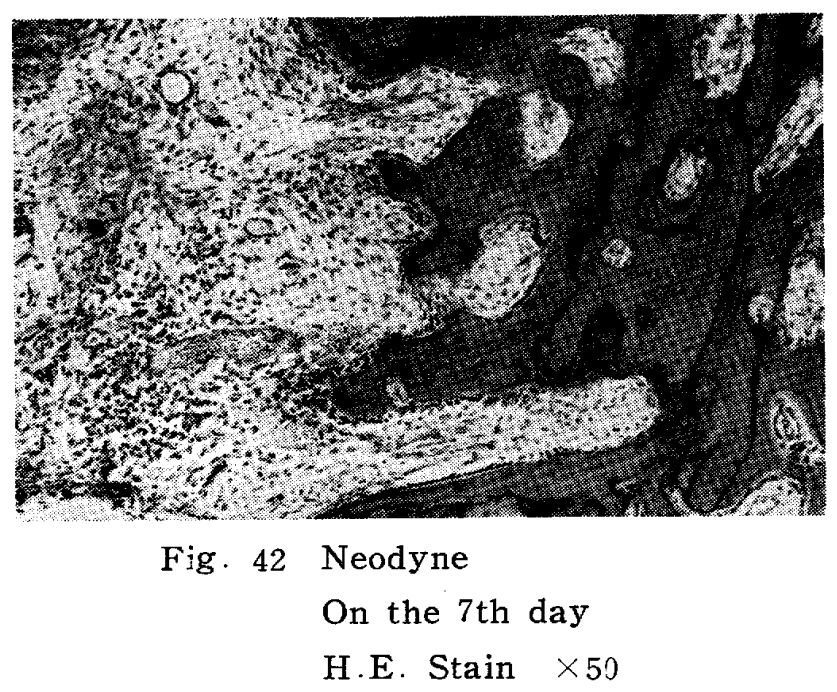

Fig. 43，44では乳蒾は根尖に至るまで完全に拔䯣さ れ僅かに充埧材が残存しているのが認められる，根尖菌 根膜には幼若な線維性結合組織が著明である。根尖部に 後継永久歯歯胚が近接している部を除いては乳歯は歯槽 骨によって囲まれ蔝根膜も一定の幅を保っている，柬小 囊, エナメル器には何ら異常所見はみられない。

乳蒾根尖部周囲菌根膜に好中球，リンパ球などの炎症 性細胞浸潤が広範团にみられる例では炎症巣に連続して 外エナメル牙細胞の一部に限局して萎縮がみられ，それ に連続してェナメル骾は変性に陷り，エナメル芽細胞は 配列不整を示している. 


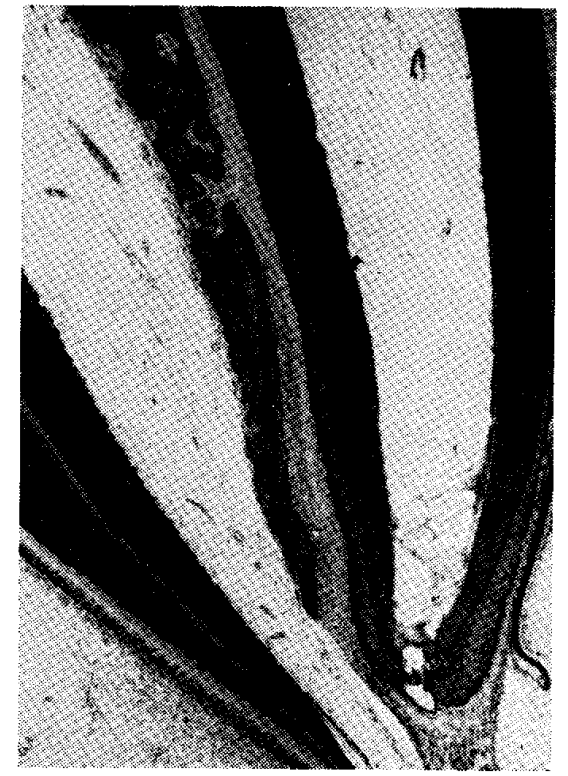

Fig. 43 Neodyne

On the 14th day

H.E. Stain $\times 20$

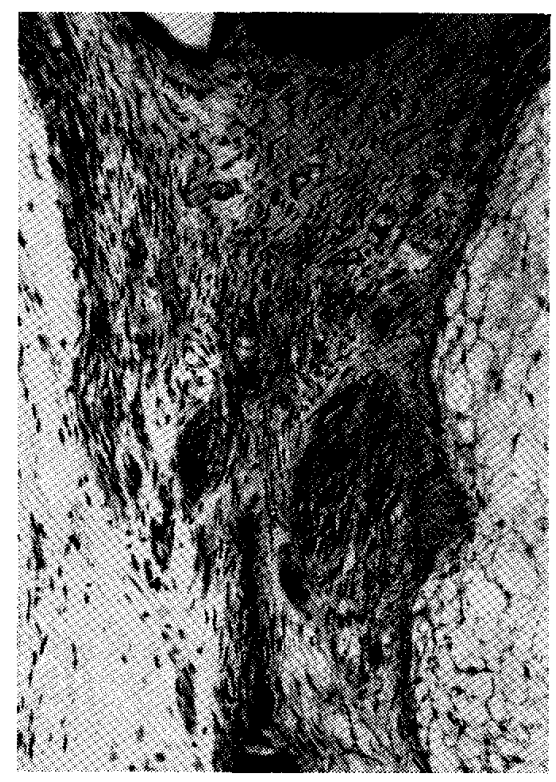

Fig. 44 A magnification of Fig. 43 H.E. Stain $\times 100$

術後 1 力月

乳蒾根は一定の長さに達しているが，根尖部は未完成 の状態にある。根管内は完全に抜髄され充填材が残存し ている．後継永久歯歯肧が近接している部では苗槽骨は 大幅に吸収され歯根膜を一層残すのみとなっている。そ れ以外の蒾根膜腔は一定の幅を保って歯槽骨によって囲 まれている，根尖部には硬組織様所見を示す一㞗が認め られる. その直下の菌根膜には限局した好中球を主体と
した炎症性細胞浸潤がみられその外側には線維牙細胞の 壃殖が著明で幼苦な結合組織がみられる。

後継永久雨雨胚についてみると，エナメル質は未石灰 化の状態にあり，炎症巣の連続した部のエナメル牙細胞 の一部に配列不整と菱縮がみられる。また中間層細胞に 連続した一部に一層の壁に囲まれた䨞胞状構造物がみら れ，中に変性に陌った細胞がみられる（Fig.45，46）。

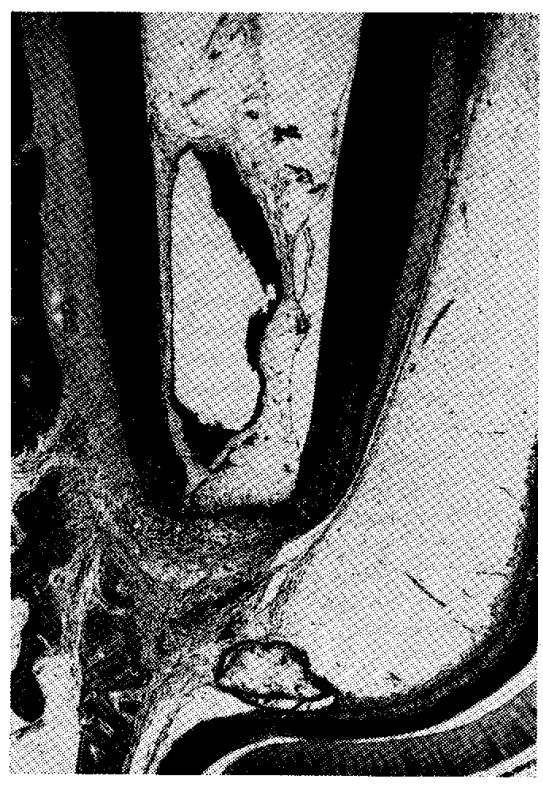

Fig. 45 Neodyne

On the 1st month

H.E. Stain $\times 20$

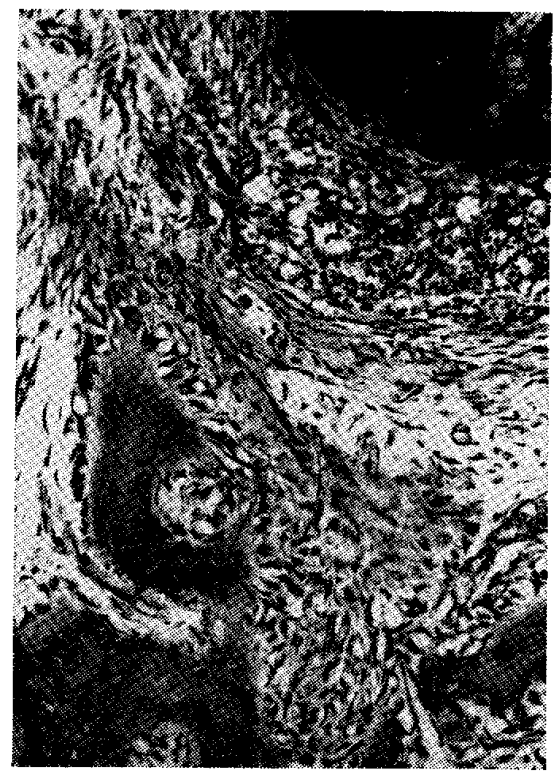

Fig. 46 A magnification of Fig. 45 H.E. Stain $\times 100$ 
術後 2 力月

乳㐘根の茵根膜腔はほぼ一定の幅を保っているが，根 側上部において一部蒌槽骨壁の bundle bone に新生さ れた骨梁の涯加がみられ䨤根側のエナメル質と癒合して いる所見がみられる。その部の㐘根膜線維束は不規則で 軽度の細胞浸潤がみられる（Fig．47）。

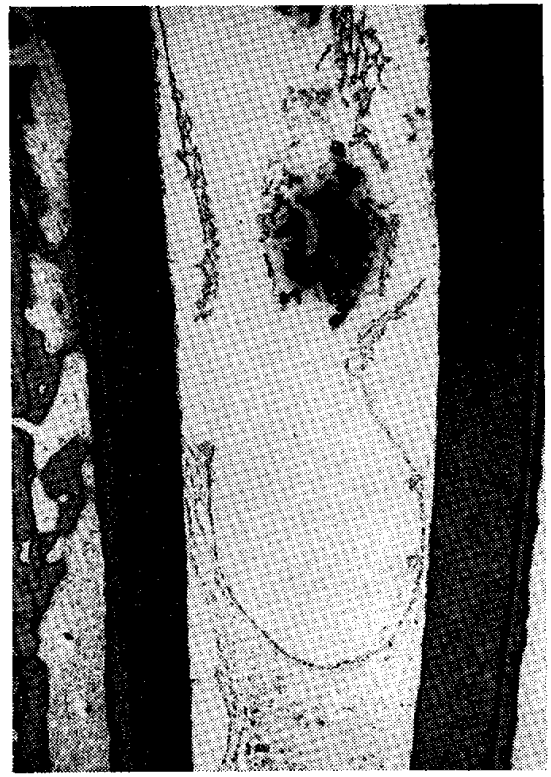

Fig. 47 Neodyne

On the 2nd month

H.E. Stain $\times 20$

根管内は完全に抜髓され，充搷材が僅かに残存してい る、根尖部の一部では破粜細胞によるセメント質の吸収 がみられる，根尖畓根膜には好中球，リンパ球などの炎 症性細胞浸潤がみられる。またその部には重層扁平上皮 で囲まれた囊胞がみられ内部には好中球が多数みられ， 上皮の然側は線維性結合組織の一層が取りまいている

(Fig. 48).

根尖直下の柬根膜から歯槽骨には広範囲にわたって壊 死層がみられ，その周囲には好中球，リンパ球などの炎 症性細胞浸潤が認められる。歯槽骨は一部吸収，消失し ている。炎症巣に近接した部の後継永久歯歯胚はエナメ ル小柱を一部残すのみでエナメル芽細胞, 中間層細胞, エナメル髄はすべて消失している（Fig．49）。

術後 3 力月

根管内は完全に抜髄がなされ充填材が僅かに残存して いる。乳歯根側の象牙質はまだ厚く吸収の所見はみられ ない.

根側のセメント質, 象牙質は部分的に吸収されてい る. 歯根膜には好中球, リンパ球, マクロファージなど

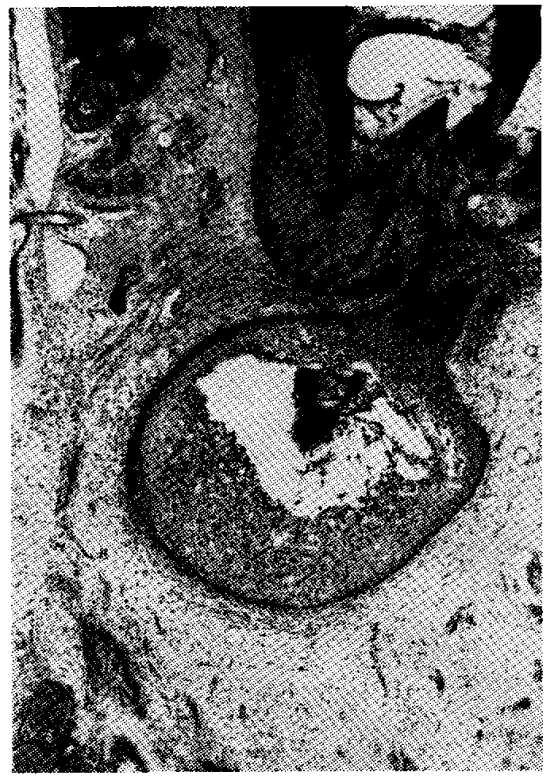

Fig. 48 Neodyne

On the 2nd month

H.E. Stain $\times 20$

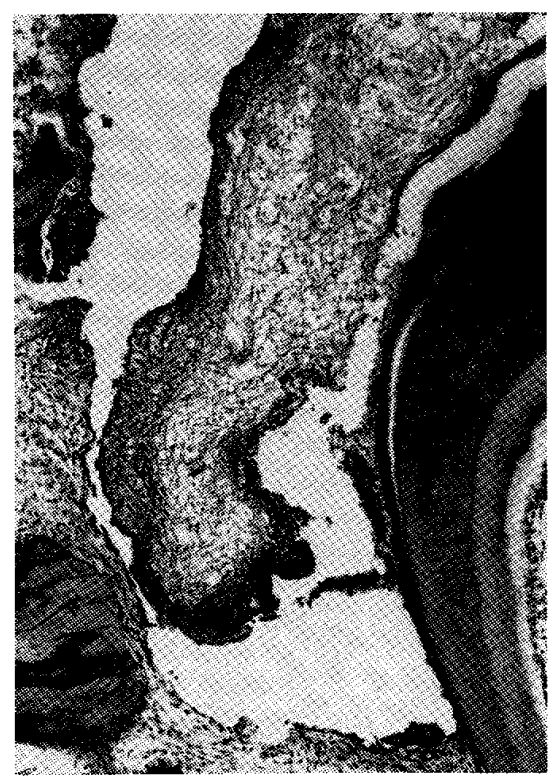

Fig. 49 Neodyne

On the 2nd day

H.E. Stain $\times 20$

がみられる。吸収部には多数の吸収細胞もみられる。ま た䨑槽骨は部分的に新生添加が行われセメント質との組 織癒合が行われておら，骨性癒着の所見を呈している (Fig. 50，51)。乙の時期に至っても乳歯根側の吸収の 伸展がないため永久歯の萌出が大きく阻害されている.

根尖雬根膜にはりンパ球，好中球などの炎症性胞細浸 潤がみられる。その外側には線維牙細胞の増殖がみられ 


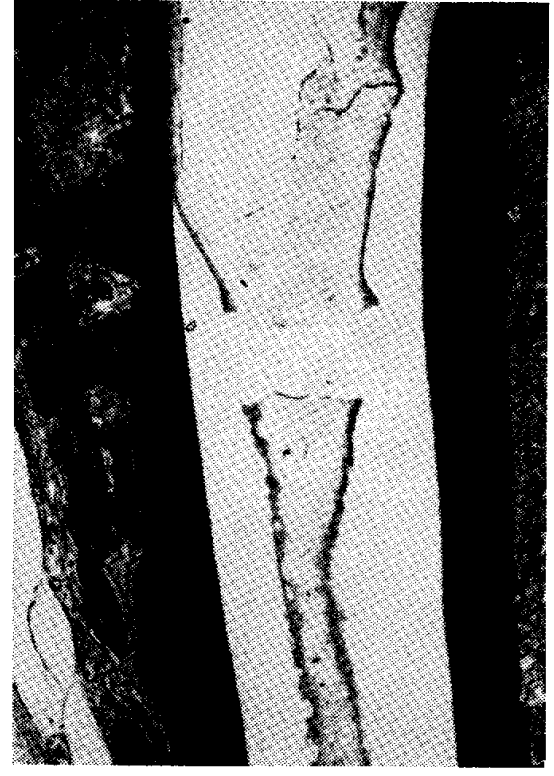

Fig. 50 Neodyne

On the 3rd month

H.E. Stain $\times 100$

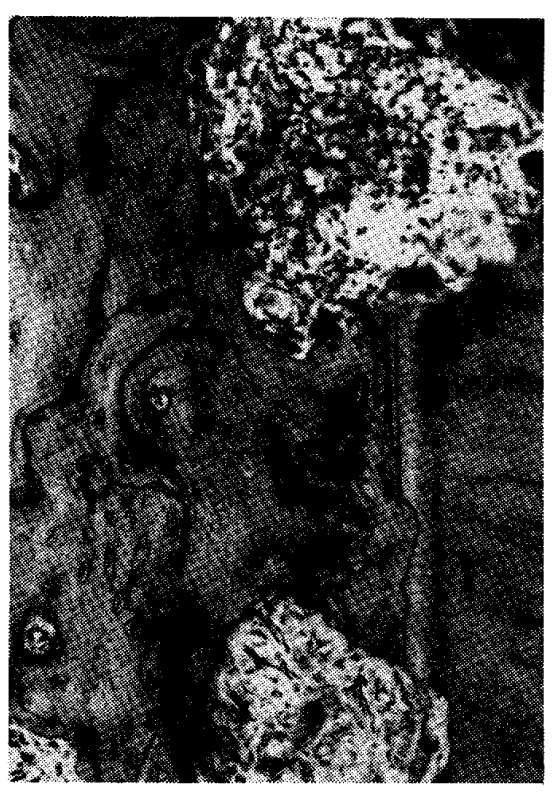

Fig. 51 A magnification of Fig. 50

H.E. Stain $\times 100$

幼若な結合組織所見としてみられる。

後継永久歯䨑胚のエナメル質は咬頭頂から歯頸部に至 るまで完全に石灰化が行われ乳歯根に近接して発育中で ある。しかしまだ匊肉上皮に被稪された状態を示してい る。乳柬根側の吸収がみられないためその部の歯根膜な らびに歯槽骨も残存している，永久歯菡肧を被覆する退 化エナメル上皮の外側は線維性結合組織がみられ，それ に接した乳雬根側の雨根膜はほとんど消失しその部はリ
ンパ球，好中球の浸潤が著明である，炎症巣に近接した 部の退化エナメル上皮には空胞化, 無構造化, 消失など がみられる (Fig．52）。永久歯は萌出遅延の状態を呈し ている。

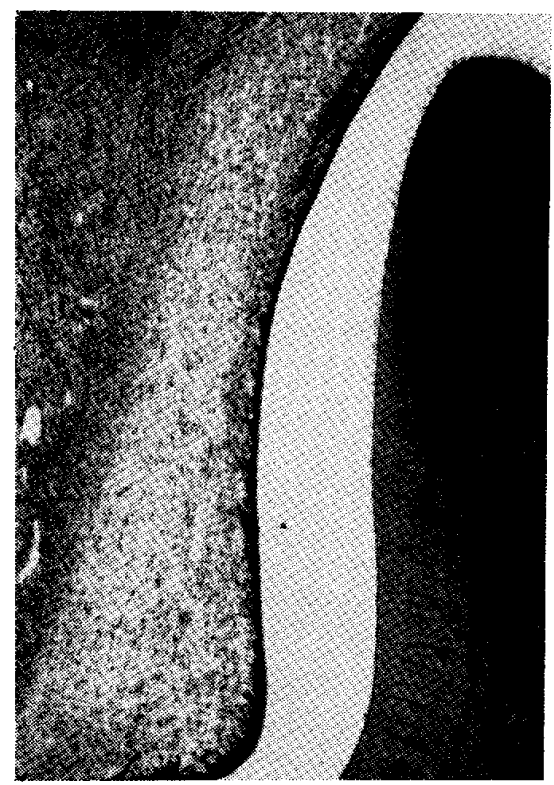

Fig. 52 Neodyne

On the 3rd month

H.E. Stain $\times 20$

FR

術後 1 週 2 週

乳菊根管内は根尖に至るまで拔䯣されている。しかし

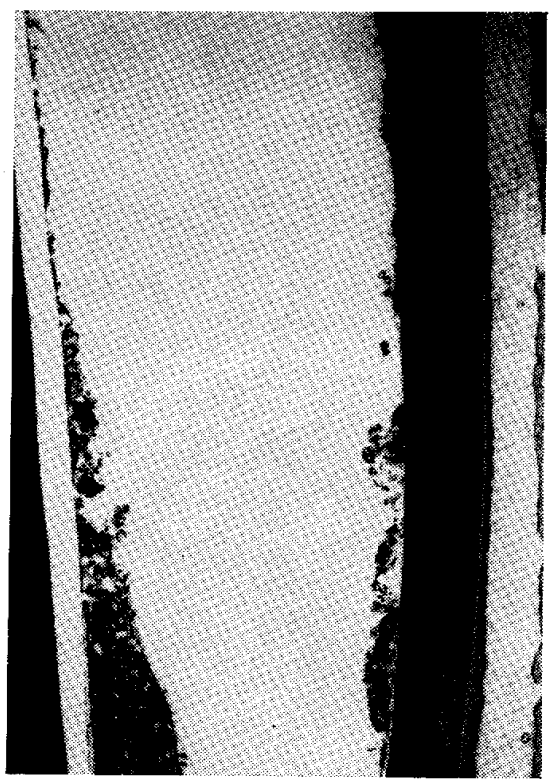

Fig. 53 FR

On the 7 th day

H.E. Stain $\times 20$ 


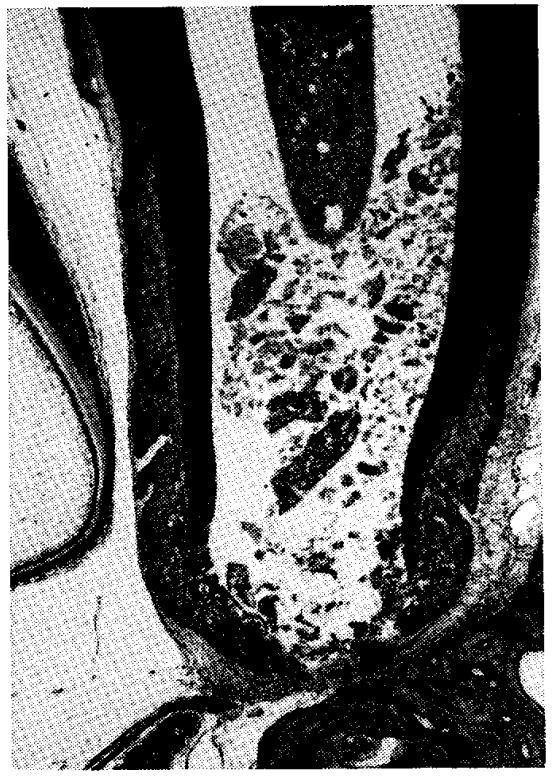

Fig. 54 FR

On the 7 th day

H.E. Stain $\times 20$

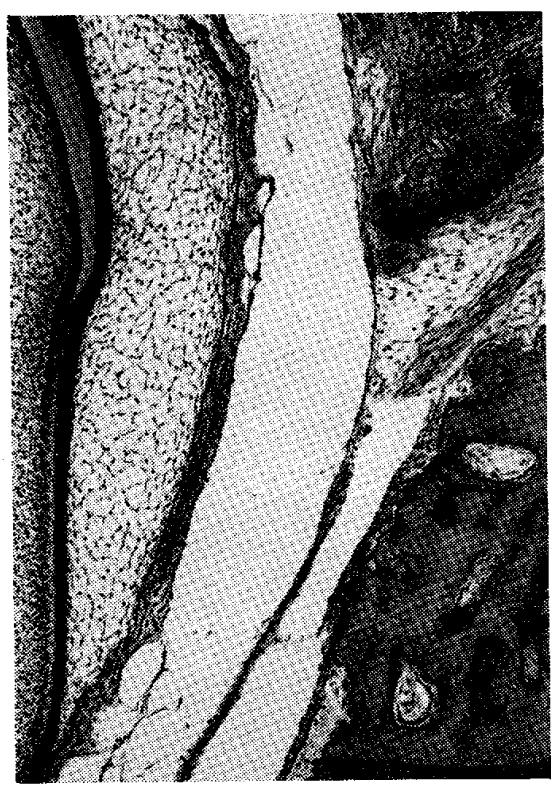

Fig. 55 FR

On the 14th day

H.E. Stain $\times 50$

充填材の残存がみられる．乳㐘の歯根膜線維束は規則正 しい配列を示している，根尖側の後継永久雪崡肧の近接 部において歯槽骨は消失し㐘根膜を一層残すのみとなっ ている。一般に永久菊蒾胚には何ら異常はみられない (Fig. 53，54）.Fig.55亿示すようにエナメル牙細胞， 外エナメル上皮細胞は正常像を保っている。

術後 1 力月
乳㐘の根头部に後継永久菌歯胚が近接した所では歯根 膜を一層残すのみで蔝槽骨は吸収し，それ以外では乳柬 は歯慒骨によって囲まれている，根尖部はへマトキシリ ンに濃染した硬組織様所見がみられる。

根尖菌根膜には限局した軽度の細胞浸潤がみられるが 大部分は線維性結合組織としてみられる，柬胚のエナメ 儿質は未石灰化の状態汇ありエナメル芽細胞の配列がー 部不規則な所もみられ，歯小露仁も軽度つ細胞浸潤がみ られる (Fig. 56)。

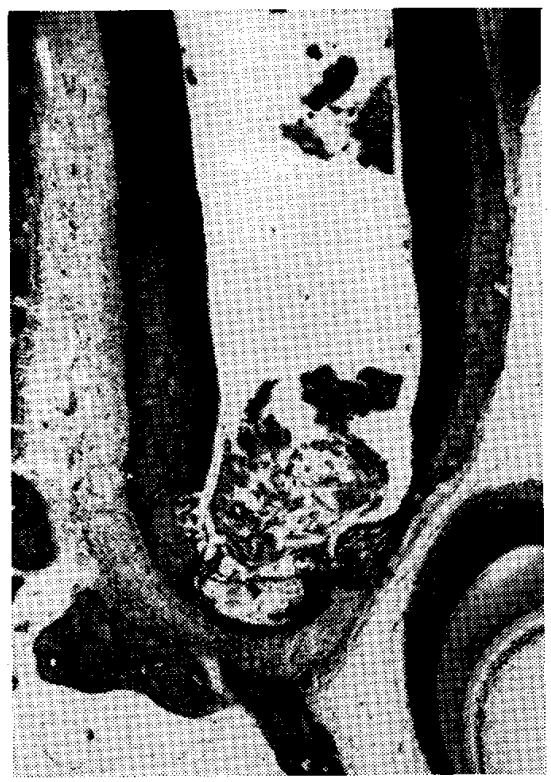

Fig. 56 FR

On the 1st month

H.E. Stain $\times 20$

充填材料が根尖䨑根膜を通して歯槽骨まで浴出した例 では充填材周囲に好中球，マクロファージなどの炎症性 細胞浸潤がみられ，線維芽細胞などの毁富な所見がみら れる。

炎症巣に近接した部の後継永久囦备胚のエナメル牙細 胞は配列が不規則で粗となり萎縮所見が強く中間首細胞 にも空胞変性がみられる (Fig. 57).

術後 2 力月

根管内は根尖部に至る沈で完全に抜髄されている．乳 歯根は蒾根側において一部蒾根膜側からの外部吸収がみ られ軽度の細胞浸潤がみられる.蒾根膜に面した bundle bone も軽度の吸收所見がみられる。根尖部歯根 膜には好中球，リンパ球などの限局した炎症性細胞浸潤 がみられ，線維㤠細胞す豊富である。

根尖部に近接した後継永久䨑蒾肧のエナメル牙細胞, 中間層細胞の配列は不規則でエナメル䯣は消失してい 


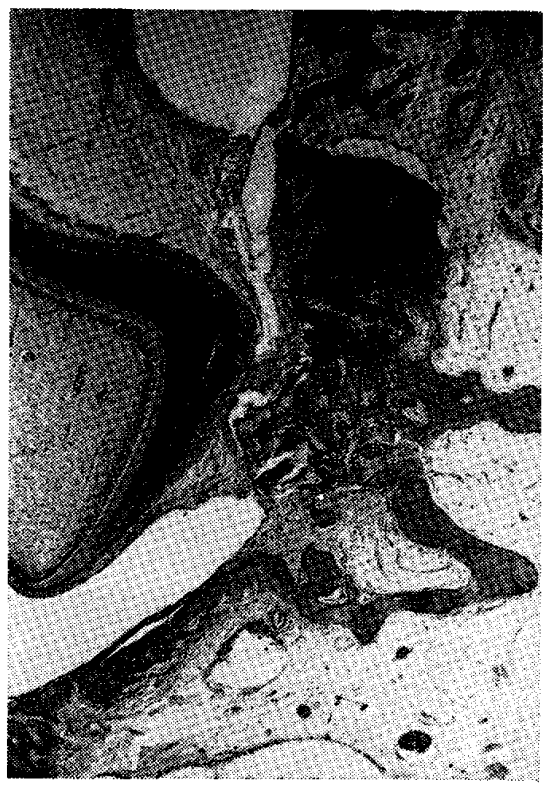

Fig. 57 FR

On the 1st month

H.E. Stain $\times 20$

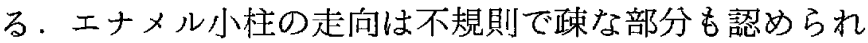
る (Fig. 58, 59).

術後 3 力月

根管内には充填材の残存が認められる。乳歯根は根側 および根尖側よりの吸収が著明である。とくに永久歯菊 胚の萌出に伴って近接した部の歯根象牙質は外部吸収が 著明で吸収面には破歯細胞が一列に並んで認められる。

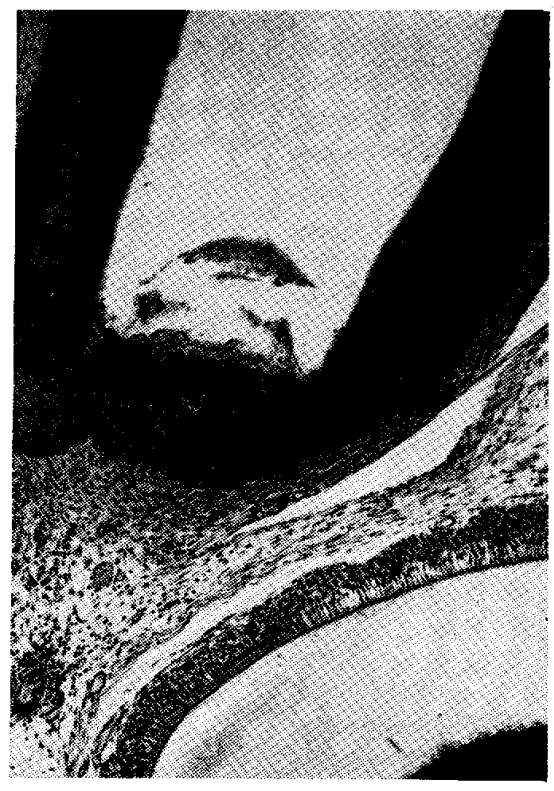

Fig. 59 FR

On the 2nd month

H.E. Stain $\times 50$

その外側の菌根膜組織は完全に線維性結合組織, いわゆ る吸収性肉芽組織によって置換されている。

後継永久歯蒾胚の咬頭頂は萌出に伴い蒾頸線上にあり 歯冠部エナメル質はすべて石灰化が十分行われ，表層部 は退化エナメル上皮として認められ，一部歯根象牙質が 完全に吸収され，充填材と退化エナメル上皮が接した部 分において上皮は壊死に陷った部を認められる（Fig. $60 \sim 62$ ).

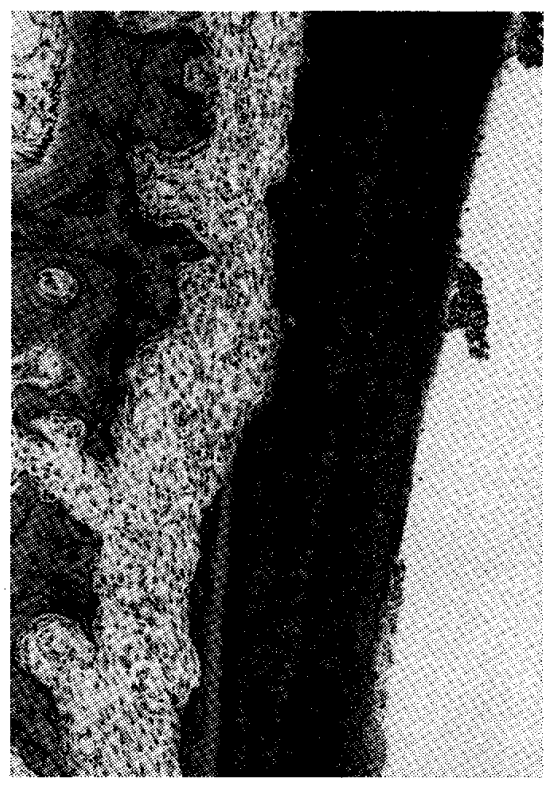

Fig. 58 FR

On the 2nd month

H.E. Stain $\times 50$

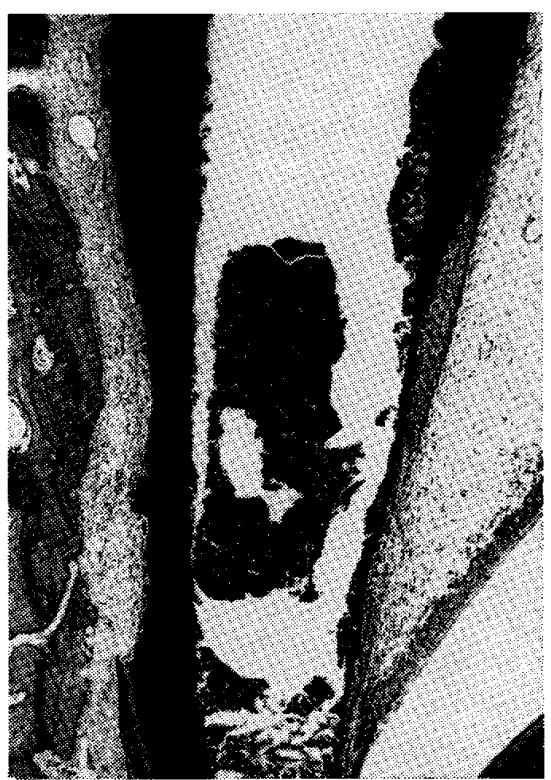

Fig. 60 FR

On the 3rd month

H.E. Stain $\times 20$ 


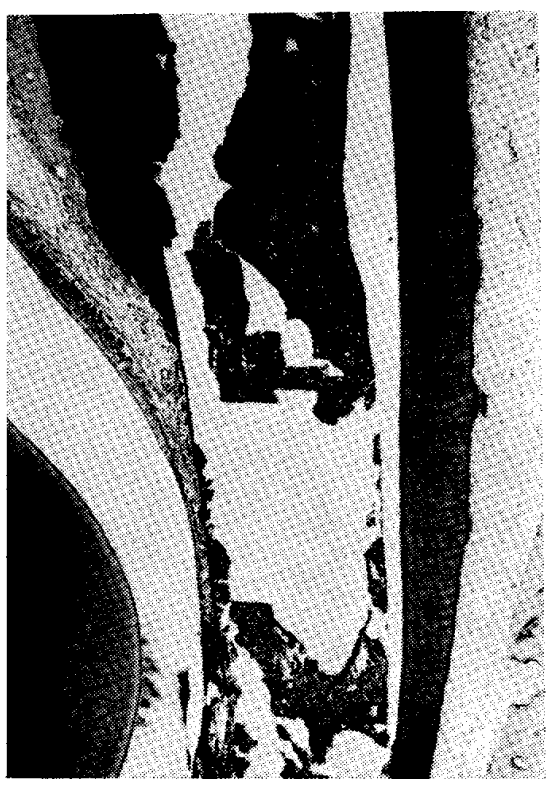

Fig. 61 FR

On the 3rd month

H.E. Stain $\times 20$

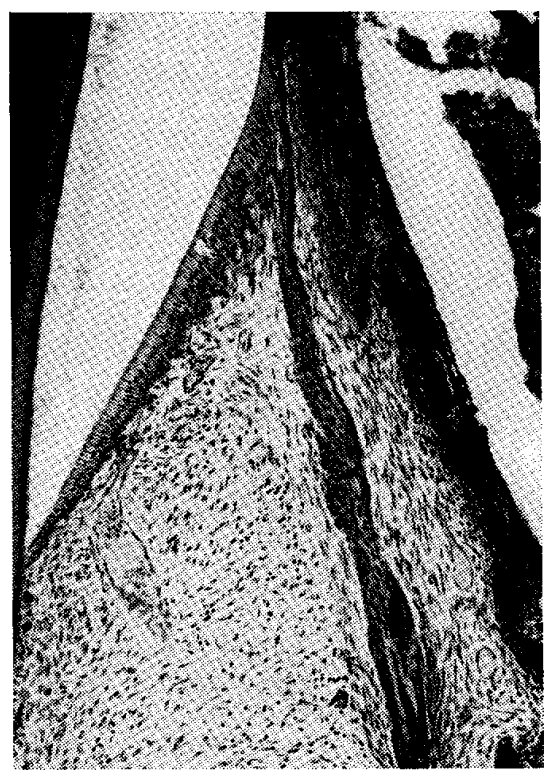

Fig. 62 FR

On the 3rd month

H.E. Stain $\times 50$

考察

雪科材料の安全性の評価について, FDI, ISO, ADA によって生物学的評価基準が提唱されている. 本研究に 用いている雨内療法材料である根管充填材料もその一つ である，

根管充填に関する研究は, Barker ら $(1972)^{6) ，}$
Starkey $(1973)^{7)}$, Coolidge (1932) ${ }^{81}$, Rabinowitch $(1953)^{9}$ などみられるが多くの報告は永久菌のもので ある. 乳歯根管立媜に関する病理組織学的研究として

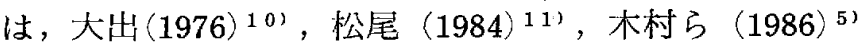
らの報告がある。

同一条件下で各種乳歯根管充填材料が柬根膜および後 継永久歯菌肧に及ぼす影響を病理組織学的に検索したも のは比較的少ない。

I . 蒾根膜の変化について

Calvital の例についてみると松尾 (1984) ${ }^{11}$ ，は幼 犬の第 2 ，第 3 乳 $⿴$ 菊を用い病理組織学的検案におい て，ほとんど资症性変化を認めることなく，根尖孔外に 薬剤を溢出させた場合でも歯根膜には限局した炎症性細 胞浸潤が認められるが軽度であったと述べている。また 長期にわたれば，炎症は消退し治癒機転をとると報告し ている、水野（1969）12'は各種根管充填剂の創傷治癒に 関して，限局性の変性壊死を認めたが， 6 力月後は治癒 良好な傾向を示したと述へ，橴谷（1980） ${ }^{13}$ 'は実験的に 根尖病巣を形成させ根管充塡後化膿の程度は劣っている と述べ，品川 $(1980)^{14)}$ は Apexification に関して根 尖部にセメント質様硬組織の形成を実証している，本研 究では炎症所見はほとんどみることなく，歯根膜に充填 材が湓出している場合壊死組織の形成を認めている. このととは松尾 $(1984)^{11}$ ，片岡 $(1971)^{151}$ の報告から も実証できる。すなわち, 細胞毒性陚験において, 細 胞の増殖にかなり顕著な抑制を示すが，培養後半におい て増殖性は対照群のそれよりも活性化し，時間の経過に よる毒性の低下を示唆している。

Vitapex については，成分中にもみられるように組 織減出液の抑制や防雷作用を目的とし消毒作用として体 液や分泌液に溶解するととにより，ヨウ素を解離すると 報告されている．松尾（1984）11'は全例において根尖蒾 根膜に空胞形成をみ，炎症性変化は軽度であり，とくに 網様萎縮を引き起こすほどの所見はみられず空胞の周囲 にもリンパ球, 組織球などの炎症性細胞浸潤も少なかっ たと報告している．また細胞毒性試験においても出現が 少ないと報告している。

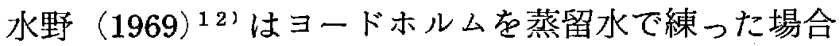
は息肉形成が認められたとし，川上ら（1979） ${ }^{16)}$ はラッ トの皮下組織を用いて，Vitapex 周囲に肉芽組織が形 成されるが，壊死組織はみられず，炎症性反応も軽度で あり, 肉芽組織には組織球が多数含まれ，それが水酸化 カルシウムを貪食すると報告している．

本研究では, 炎症性細胞浸潤と空胞形成がみられた。 
また歯根側では，セメント質に歯槽骨の新生添加がみ られ組織癒合がみられ骨性癒着を示す所見もみられた。

Kri I についてみると，ヨードホルム製剤は Walkoff (1960） ${ }^{17)}$ の報告にみられるように古くから用いられ，臨 床に広く忍用されている.Kri I は, 主成分がヨードホ ルムであるため，一般的には感染根管治療に扔ける根尖 病㮺の症例においては比較的良好な成績をおさめている ことは周知の通りである．根尖病巣のある場合には根尖 孔外に溢出させた方が良好な成績が得られたるする報告

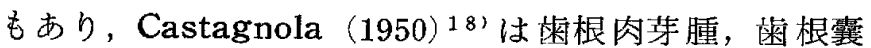
胞の例では良い結果が得られると述べている。しかし， 本研究にもみられるように非感染根管における㐘根膜の 作用についてはヨードホルムが歯根膜組織に炎症を惹起 することは森田 $(1935)^{191}$ ，花沢ら $(1937)^{201}$ の報告と 一致している.

木村ら (1986) ${ }^{5}$ )の報告によると歯根膜に対しては炎症 所見がみられるため, 根尖孔外に溢出はさせない方が得 策であると述べている．本研究でも木村ら (1986) ${ }^{5}$ ) とほ ぼ同様な結果を得ている。吉田ら (1968) 21'は Kri I を 皮下組織に埋入した実験において 5 週目位に至ると，炎 症性変化は消失し，糊剤はほとんど肉芽組織により置換 吸収されると述べている。

Neodyne 亿関しては, 主成分が酸化亜鉛ユージ， ールで, 粉末心酸化亜鉛60.0\%, 水酸化カルシウム 15.0 $\% ，$ ロジン $25.0 \%$ を含有している. 液は $100 \%$ ユージノ 一ルである. Barker $(1972)^{6}$ 忋犬の永久歯在用いて酸 化亜鉛ユージノールで根管充填を行い骨性癒着を認めて いる. 大出 $(1976)^{10)}$ も同様な所見を得ている.

Coolidge (1932) ${ }^{81}$ はユージノールの組織反応をみ,松 尾 $(1984)^{11}$ は動物実験により, 大出 $(1976)^{10)}$ とほほ 同樣な所見を認め霆根膜に膿瘍の形成を認めている.

大出 $(1976)^{10)}$ は根尖部周用組織に著明な炎症性変化 を認め, 根管充填㓮が根尖より溢出した場合は膿汮の形 成や歯槽骨の吸収も認めたと述べている. Barker (1972) 6) らは犬の下顎小曰歯に酸化亜鉛と gutta perchaによ る根管充填を行った結果, 根尖部歯根膜の炎症性反心は 即時根充や過剩根充の場合一時的なるのであり, 線維性 結合組織による治㿁が行われると述べている，木村ら (1986) ${ }^{5)}$ は贯根膜に直接作用させると強い炎症性反応を 惹起するが，根尖部のセメント質を介しておれば炎症性 反応は軽度であると述へている．水野（1969） ${ }^{121}$ は線維 化の治癒傾向を認め刺激性の少ないものであると述へ

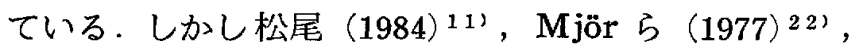
Pettersen ら $(1977)^{23}$ 弓 らは細胞毒性試験において高い
毒性を有すると述べている，本研究では，乳囷根尖部の 周囲蒾根膜に好中球，リンパ球などの炎症性細胞浸潤が みられ，霜槽骨にまで炎症の波及している例もみられた。 また歯根側のセメント質は吸収され霜槽骨の新生添加に より組織癒合が行われ骨性癒着の所見が認められる，骨 性痹着に関する報告としては, Euler Meyer (1927) 24) はセメント質, 霜槽骨の両方に骨源加が起こるが, セメ ント質か歯槽骨の一方に骨添加がみられ骨性癒着が起こ るとし，Römer (1928) ${ }^{25}$ は炎症あるいは外傷により 歯根側のセメント質が吸収し，その歯槽骨面に骨の添加 がみられ，歯根に contact することによって癒着が起と ると述べ, Kronfeld ら $(1940)^{26)}$ は外傷により雪根膜 に炎症が起こり，二次的変化として起こるとし，Beiderman (1962) 27) は咬合圧, 外傷, 遺伝, 代謝異常説をと り, Pindborg $(1970)^{28}$ ) は外傷, 再植, 移植の場合である とさまざまな報告がみられるが，乙れらは永久歯のもの で乳歯による報告はほとんどない，そてで本研究につい ての骨性癒着との関連性をみると, (1)充填材の刺激が象 牙細管に伝わる，(2)セメント質を通してさらに霜根膜に 炎症を惹起，(3)長期間慢性の持続性の刺激により吸収細 胞の出現がみられる. (4)吸収細胞の出現はセメント質あ るいはそれに面した茵槽骨に惹起される。（5歯槽骨は新 生添加が旺盛となりセメント質内に伸展し組織癒合を起 こす.他方, 歯根吸収時期と充填材の刺激が同時に歯根膜 に現われた結果であることも無視することは出来ない。 榎（1943）291の報告による乳歯交換期にみられる吸収と 添加の異常により起てる説とは全く異っている. Pindborg $(1970)^{28}$ が述へている後継永久雨の存在に関係 なく惹起するという説とはこの部分では一致性をみる。 大出 $(1976)^{10}$ は抜髄, 機械的刺激, 化学的刺激により 歯根膜に炎症，壊死，変性が起こり肉牙組織の増殖によ り骨芽細胞の一部出現に上り新生骨の形成に上っ癒着を 起とすと述べている．さらに骨性㾍着を起てすととによ り臨床的には後継永久霜の萌出遅延は本研究でも認めら れた。しかし榎 $(1943)^{29)}$ ，坂井ら $(1975)^{30)}$ の報告にみ られる低位乳臼歯との関連性については本研究では明ら かではない．FR は木村ら（1986） ${ }^{5}$ の報告によると根 尖直下の歯根膜に直接作用すると，限局した好中球を主 体とする炎症性細胞浸潤が認められると述べている．本 研究についても木村ら (1986) ${ }^{5}$ ' の報告と一致性をみる. FR は高橋 $(1956)^{31}{ }^{\prime \prime}$ が発表したものでグアヤコールと ホルムアルデヒドの縮合物である．竹中ら $(1980)^{32}$ は FR の消毒效果について Staphylococcus aureus に対 する発育阻止作用を検討し， CC と同程度かそれよりや 
や弱いと述べている.しかし他の根管充填材に比べはる かに低いと報告し，一方では組織親和性から考えると治 瘑機転に関してはむしろよいと述へてている，木村(19 78) ${ }^{33)}$ は FR を用いて加任根管充填法を行い， FR のも $\supset \mathrm{Ca}^{++}$イオン交換作用や持続性の抗菌性，歯根膜に対 する治癒促進作用を有し，感染根管治療に対しても满足 のいく結果が得られると報告している．高橋ら（1968） 34) は成熟マウスの背部皮下結合組織内に FR を注入し 組織学的に検索を行い，薬剤に接した部には炎症性細胞 浸潤，壊死層がみられるが，肉芽組織の活発な所見がある と述べている. Guttuso（1963３３）は生体反応は材料の 刺激によって修復するか壊死に陷ると述へ，鈴木 (1966) 36) は FC をウサギの皮下に埋入し樹脂状物の形成をみ ていることからも FR はフェノール系化合物でもグア ヤコールとホルマリンの縮合物であるととから刺激は減 弱されていることが考えられる。

II . 乳菊の雷根吸収について

乳歯の歯根吸収を述べるとき，歯䯣が生活していると とにより，生理的に自然に吸収現象が行われているてと はいうまでもなく画髄が重要な役割を演じている。

一般に歯根の忣収現象は，歯髄側よりの内部吸收之歯 根膜からの外部吸収に上り均衡保って歯根の吸収が行 われている、本研究のように䒩䯣完完に除去すれば外 部吸収と永久歯歯胚の萌出力により主に歯根の吸収が期 待される．乙のととは高橋 $(1936)^{37}$ の報告と一致性を みる。しかし一方では歯随は根の吸収に関与していない という Krontfeld (1932) ${ }^{38)}$, Sicherら (1962) ${ }^{39)}$ ら の報告もみられる。

本研究でみられるように対照群で述べているように米 髄内の吸収は髄角部付近にまで及んでおり, 内部吸収と 外部吸収がバランスをとりながら，歯根象牙質の吸収に 関与していることは明らかである．Mjör (1973) ${ }^{401}$ は 乳蒾歯䯚道の壊死や根尖周囲の炎症は吸収を停止させると 述べ，須賀 $(1971)^{41}$ ) は破骨細胞の酵䒺の活性度が強 く，それが障害を受けると歯根の吸収にも影響があると 述べている．そてで充填材の影響により，歯根膜に炎症 を薏起すると正常な外部吸収に比へ，雨根膜側からの外 部吸収に何らかの影響を及ぼしていると考えられる。ま た本研究でみられるように Vitapex, Neodyne の例で は骨性癒着の所見がみられることから当然歯根吸収の遅 延がみられるとともに，後継永久歯蒾胚の萌出遅延が喼 められる。

III. 後継永久雬菡胚の変化について

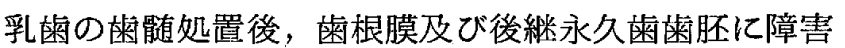

を起こすととがある．Lartschneider $(1909)^{42)}$ は永久 歯のエナメル質の形成異常には乳溇の根尖病巣によるも のがあると報告して以来, 臨床および病理組織学的に Turner $(1912)^{43}$ ), Siegmund und Weber $(1926)^{44)}$, Bauer (1932) ${ }^{45)}$, Morningstar (1937) ${ }^{46)}$, Hals ら (19 58）47らの報告がみられる。我国に扔いては大塚(19 54) ${ }^{48}$ ， 熊本 $(1960)^{49 \prime}$ ，松本ら (1977) 50) らによって根 尖病巣を作り，後継永久茵のエナメル質に減形成が起こ ると述へてている．松尾（1984）11'は幼犬の実験的研究に おいて, 根父孔外に多量の充填材を益出させないかぎり 後継永久歯柬胚の器質的変化はみられなかったと報告し ている. 大出 $(1976)^{10)}$ は炎症病巣に近接した部分に， エナメル器に限局して変化が起っていると述べている.

本研究についてみると，Calvital の例では充填材が 完全に抜鹃された根尖部まで到達している例について も, 根父孔外に益出している例でも, エナメル器には何 ら異常所見がみられないととを実証している。

次に Vitapex の例についてみると，根尖孔外に充填 材が溢出した例では菌根膜に炎症所見がみられ，炎症巣 に近接した部のエナメル器にはエナメル芽細胞に扁平 化，萎縮，融解像を認めている，拔髄が完全になされ充 填材が根尖部までスムーズに到達している例ではエナメ ル器には何ら異常所見はみられない，3力月経過例にお いて，エナメル質は十分石灰化が行われている例で退化 エナメル上皮に资症が波及しているのが認められるが， エナメル質はすでに形成を完了していると思われ，炎症 による二次的変化がエナメル質に障害を与えているとは 思わない。

Kri I の例については，一般に炎聇性細胞浸潤がみら れ, 比較的エナメル器には著明な変化がみられ, エナメ 儿質形成不全歯も認められる．またすでに退縮を始めて いる退化エナメル上皮に炎症が波及し, 萎縮, 扁平化が みられる、歯根膜を通した局所の炎症があることからタ ーナー菌も十分考えられる。

本研究を通して永久柬菊胚の影響を観察してみると, とくに充填材による化学的刺激が大きく作用するが，と くにエナメル器周囲のすべての細胞, 䔼小囊は外来刺激 に対して強い抵抗性をもっていると考元られる。

允填材により乳歯の根尖部に资症があると永久歯歯胚 に障害を起こすととは実証された。とくに臨床において は乳白雨は最もう蝕にかかりやすく，進行性であるた め，歯根膜炎を惹起しやすく小田茵胚は木村ら (1986) 5) の報告にもあるように, ターナー柬の発現が考えられ る。 
以上のととから乳歯の根管允填材は粷根吸収時, 未完 成歯においては充午材を直接雨根膜に作用させないよう に注意を払うことが必要であり，根尖孔外の充填材への 溢出は，永久歯曾胚に影響を与えることは事実であり， 極力さける事が必要で, 実際に実験を通じて, 松尾(19

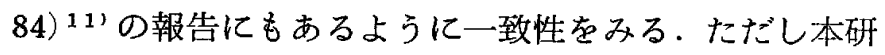
究はあくまでも正常䨑根膜に対する影響であり, 感染に よる歯根膜の炎症時の充填に関しては今後の検討の余地 があると思われる。

Neodyne の例では根尖部霜根膜に炎症所見がみられ， 近接した外エナメル牙細胞に限局した萎縮がみられ，エ ナメル髄は変性に宿り，エナメル牙細胞は配列不整を呈 すものから消失したものまで認められた．またエナメル 質がすでに形成を完了した退化エナメル上皮の部，いわ ゆる退縮を始めている例に炎症巣が波及し, 空胞化, 無 構造化, 消失などを認めている. 大出 $(1976)^{10}{ }^{0}$ は同じ 成分をもつ充填材に扔いて, 炎症性の変化に伴い永久菌 歯胚のエナメル器の細胞は配列不整, 萎縮に陥っている と述べている. 木村ら (1986) ${ }^{51}$ は Neodyne について 歯根膜に直接作用させると強い炎症性反応を示すが, 充 填材が根尖部でおさまっていると炎症は軽度で, 後継永 久柬に及ぼす影響は少ないと述べている。

FR については, 充填材が霖根膜を通して歯槽骨まで 炎症が波及した例において近接したエナメル芽細胞に配 列不整, 萎縮所見がみられ, 中間層細胞に空胞変性を認 めている.またエナメル質がすでに形成を完了した退化 エナメル上皮の部に眯な結合組織内に残存した立填材が 接触し退縮した上皮が壊死に宿った例を認めている。木 村弓 (1986) ${ }^{5)}$ は刺激性は少なく, 永久歯歯胚に及ふ障 害はほとんどないと述べている。

IV. 永久柬の萌出について

本研究では対照群においては乳歯根の吸収に続いて永 久歯の萌出がスムーズに行われている. 術後 3 力月経過 例では乳歯根の吸収において歯鹃腔の内部吸収は, 䯣角 部付近に至るまでみられ, 後継永久歯の咬頭頂は茵頸線 上にあり, エナメル質の石灰化は完了し, 退化エナメル 上皮は蒾の萌出によって口腔上皮と癒合している.また 隶根膜の新生が認められ, 結合組織内に骨梁の活発な発 育が行われている.Masslerら (1941) ${ }^{511}$ は歯の萌出の 因子について, 蒾根象牙質の発育, 苗鹃, 蒾根膜内の血 管の作用, 細胞の増殖, 歯槽骨の吸収, 蒾槽突起の作用 などを挙げている. Ten Cate (1969) ${ }^{52}$ は歯根の発育 (ヘルトウィッヒ上皮鞘の発育その他), 骨の発育, 歯胚 と歯槽骨に介在する結合組織変化について述べている.
本研究のように実験群においては根尖部霜根膜に炎症を 惹起する充填材がエナメル器の細胞に明らかに障害を与 えているのは事実であり, 䨑根膜に惹起された炎症性変 化, 乳歯根の吸収の遅延, 周团霜槽骨の吸収状態は Vitapex, Neodyne の例で認められた。骨性癒着など が関連して対照群に比べて実験群は永久歯の萌出遅延が 認められた. このように歯髄を完全に除去し, 外部の吸 収のみの荬根の吸収と充填材の影響に上る萌出遅延は明 らかである.とくに菌根膜, エナメル器を含む炎症性変 化が大きな障害となっていると考えられる．すべての症 例において永久雷の雨根の発育と形成には充填材による 影響は何ら喼めていない。障害を受けていない雨胚の 萌出のみについて考えるならば，Krontfeld (1932) ${ }^{38}$ は歯胚の根尖䨑槽骨に骨梁の形成をみ，上方に発育する ことによると述べ, Ness (1967) ${ }^{53}{ }^{\text {) }}$ は㐘根膜に存在する 線維芽細胞の収縮によると報告し, Main ら (1966) ${ }^{54}$ は歯胚と歯槽骨の間に介在する結合組織によるとし， Thomas (1967) ${ }^{55)}$ はコラーゲン線維の成熟によるもの で物理的力が加わることにより, 歯牙の萌出が行われる とするさまざまな報告がみられる．乙のような流れの中 で先にも述べたように本研究に関して永久霜の萌出を考 察すれば, 抜髄から根管充媜に至る機械的刺激, 化学的 刺激の影響により乳雨を取りまく細胞と周囲組織の変 化, さらにエナメル器を中心とする炎症性変化が周囲組 織に大なり小なり影響を及ほしているてとから萌出遅延 を惹起したと考えられる.そこで臨床に用いる根管充填 材がいかに歯内療法にとって重要な役割を演じているか 実証できるとともに生体の一部の組織の安全性の評価に も関連するものである。

\section{結論}

乳雪根管充填材料 Calvital, Vitapex, $\mathrm{Kri} \mathrm{I}, \mathrm{Ne}-$ odyne および FR t用いて, 乳歯歯根膜および後継永 久霜雨胚に及ぼす影響を生後 3 力月前後の幼犬を用いて 病理組織学的に検索を行った結果, 次のような結論を得 た。

1. Calvital の例では乳電の根尖䨑根膜にほとんど 炎症性変化を認めないが, Vitapex, Kri I, Neodyne および FR は炎症性変化を惹起する。

2. 乳蒾根の吸収所見は対照群に比べ根管充填を施 した全例において遅延が認められた。Vitapex および Neodyne の例では乳歯根と歯槽骨の骨性痹着が認めら れた。

3. 後継永久粜蒾胚の変化は, Calvital の例ではエ 
ナメル器紐胞に変化は認められない, Vitapex, FR の 例では, 充填材が湓出した場合にエナメル器細胞に扁平 化, 融合, 融解像, 配列不整, 菱縮などが認められた。 Kri I の例ではエナメル器細胞は扁平化, 萎縮がみられ る. Neodyne の例では, エナメル器細胞の配列不整, 萎縮か認められる。

4. 永久歯の萌出については, 対照群に比べて歯根膜 に惹起された炎症性変化, 乳荬根の吸収遅延, エナメル 器細胞の変化などにより, 永久霜の萌出遅延が認められ た。

5.Vitapex, Neodyne の例ではとくに骨性癒着が 䜑められ永久雬の萌出に障害が認められた。

6. 歯根膜および後継永久菌歯胚のエナメル器細胞に 及ぼす影響は Calvital, FR, Vitapex, Kri I, Ne- odyne の順であった.

7. 非感染根管治療に抢ける乳雪根管充填材料は, 乳 䨑根未完成歯への応用や，根尖孔からの溢出は歯根膜扔 よび後継永久菌茵胚に与える影響が大きい。

稿を終わるにあたり，終始御愁切なる御指導と御校閲 を睗った木村光孝教授に深葚なる感謝の意を捧げます。 また御助言と御教示を賜った九州崡科大学前学長上野正 康教授に厚く御礼申し上げます，あわせて，種々の御協 力を戴きました九州歯科大学小児望科学教室員各位に感 謝致します。

本論文の要旨は昭和 61 年 9 月 7 日（日），第 34 回九州 学校保健学会において発表した。

\section{引用文 献}

1) Stanford, J.W. : Recommended standard practices for biological evaluation of dental materials. Int. Dent. J. 30:140-188, 1980.

2) Working group 5 of the FDI Commission on Dental Products : Biological evaluation of dental materials. ISO Technical Report 7405. ,1983.

3 ) Stanley, H.R. (Chairman): American national standards institute/American Dental Association document No.41 for biological evaluation of dental materials. J. Am. Dent. Assoc. 99 : 697-698, 1979.

4 ）佐藤温重 : 粜科材料の製造の承認申請に必要な安全性試験項目案の作成，雬科材料の安全性評価法の確立に 関する研究．昭和59年度厚生科学研究費補助金研究成果報告書. $1-7,1985$.

5 ）木村光孝・内上堀征人・森高久恵・鬼塚一徳：乳雨根管古媜材料汇関する研究. 一特に歯根膜並びに後継永 久審雨胚に及ぼす影響一, 歯科材料の安全性評価法の確立に関する研究. 昭和60年厚生科学研究費補助 金 (特別研究事業) 研究成果報告書. 41-50，1986.

6 ) Barker, B.C.W. and Lockett, B.C. : Reaction of dog tissue to immediate root filling with zinc oxide cement and gutta percha. Aust. Dent. J. 17:1-8, 1972.

7) Starkey, P.E. : Pulpectomy and Root Canal Filling in a Primary Molar. Report of a Case. J. Dent. Child. $40: 209-212,1973$.

8 ) Coolidge, W. : Reaction of dog tissue to drugs used in root canal treatment. J. Amer. Dent. Assoc. $16: 747-759,1932$.

9) Rabinowitch, B.Z. : Pulp management in primary teeth. Oral Surg. Oral Med. Oral Path. $6: 542-550,1953$.

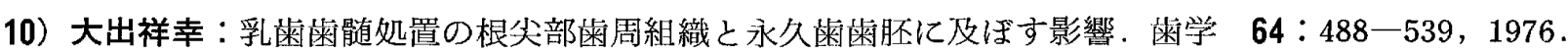

11）松尾和廣：乳歯根管充媜に関する実験的研究. 九州雨会誌 $38: 241-268,1984$.

12）水野正敏：各種根管充填剤の創傷治癒におよぼす影響について (根管模型実験)。日保雨誌 $12: 58$ - 77 , 1969.

13）渋谷俊之：根管允填用パスタの改良に関する実験病理学的研究．菌科学報 $80: 417-446,1980$.

14）品川光春：歯根未完成歯の根尖閉鎖に関する実験的研究. 九州歯会誌 $34 ： 355-376,1980$. 
15）片岡寿平：各種根充鼡の組織刺激量に関する実験的研究 (in vitro). 歯科医学 $34: 961-976,1971$.

16）川上敏行・中村干仁・林 俊子・林 重夫：ヨードホルム・水酸化カルシウムパスタ（糊剤根管充填材ビ タペックス）の組織埋入に関する実験的研究．第 1 報 病理組織学的検索. 松本雪学 $5: 35-44$, 1979.

17) Walkoff-Hess : Lehrbuch der Konservieren-den Zahnheilkunde, Johann Ambrosius Barth, Leipzig, 1960.

18) Castagnola, L. : 1000 Faelle von Gangraenbehandlung nach der Walkoffschen Methode aus dem statistischen Material. Ihre Resultate in Klinischen, roentgenologischer und bakteriologische Hinsicht. Schweiz. Mschr. Zahnheilk. 60:1033-1076, 1950.

19）森田貞雄: 崡牙保存療法の実験的研究, $\mathbb{N}$ 根管治療, (2)グッタペルカポイント・クロロパーチャ一併用及び 沃度フオルム糊㓮根管充填後に於ける菌牙周囲組織の変化. 日本蒾科学会雑誌 $28: 859,1935$.

20）花沢 鼎・近藤三郎・松宮誠一・関根永滋・松井隆弘：種々なる根管充填に関する実験的研究（第一回報 告). 歯科学報 $42: 481-495,561-584,662-686,1937$.

21）吉田定宏・窪田隆一・加登順子・祖父江鎮雄 - 古布 明 - 鶴田昭雄 - 邑上 建 - 石田鐵男 - 西野瑞穂 - 西田 百代：主として乳歯根管充填剤として用いたヨードホルム系糊戍 Kri I の臨床成績. 小児雬誌 6 ： $21-27,1968$.

22) Miör, I.A., Pettersen, A.H. and Skogedal, O. : Biologic evaluation of filling materials. A comparison of results using cell culture techniques, implantation tests and pulp studies. J. Int. Dent. $27: 124-129,1977$.

23) Pettersen, A.H. and Helgeland, K. : Evaluation of biologic effect of dental materials using four different cell culture technique. Scand. J. Dent. Res. $85: 291-296,1977$.

24) Euler Meyer : Pathohistologie der Zähne J.F., Bergergmann, München, 1927.

25) Römer, O. : 2. Verdauungsschlauch. In : Die Pathologie der Zähne. Handbuch cpéz. path. Anat. u. Histol. N, Julius Springer, Berlin, 1928.

26) Kronfeld, R. and Weinmann, J. : Traumatic changes in the periodontal tissues of deciduous teeth. J. Dent. Res. $19: 441-454,1940$.

27) Beiderman, W. : Etiology and treatment of tooth ankylosis. Am. J. Orthodontics. 48:670$684,1962$.

28) Pindborg, J.J. : Pathology of the Dental Hard Tissues, Munksgaard, Copenhagen, $1970,362-365$.

29）榎 恵：低位乳白歯と埋伏乳臼歯. 日矯蒾誌 $11: 22-28,1943$.

30）坂井正彦・平山コズエ・伊藤憲春・柏木朗男・小早川幸雄：経年的観察を抢こなった低位乳甶歯の 1 症例. 柬学 $63: 184-190,1975$.

31）高橋忠一：グアヤコール・フォルムアルデヒード・レジンの歯科応用に関する実験的研究（その1）（その 2 ). 歯学 $43: 34-68,1956$.

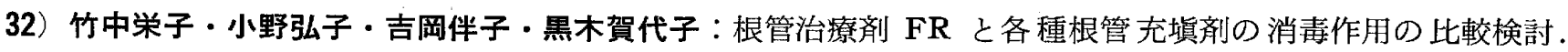
村上研究所報 $5: 1-5,1980$ 。

33）木村光孝：FR を用いた加圧根管充淖法. 歯科ジャーナル $7: 570-574 ， 1978$.

34）高橋忠一・林 俊郎：各種生活歯骮覆罩剤, 並に根管充填郕に対する組織反応についての実験的研究（第 1 報)。歯学 $56: 249-264,1968$.

35) Guttuso, J. : Histopathologic study of rat connective tissue responses to endodontic materials. Oral Surg. $16: 713-727,1963$.

36）鈴木蜸策：根管充填に関する二，三の閵題．柬界展望 $22 ： 882-884 ， 1966$.

37）高橋新次郎：歯牙交換の研究. 口病誌 $10: 1-35,140-155,1936$. 
38) Krontfeld, R.: The resorption of the roots of deciduous teeth. Dent. Cosmos. $74: 103-120$, 1932 .

39) Sicher, H. and Bhaskar,S.: Orban's Oral histology and Embryology, 5th ed., C.V. Mosby Co., St. Louis, $1962,316-329$.

40）Mjör，I.A.：人の雪の組織学（久米川正好, 他訳)。書林, 東京, 1973, 165-181.

41) 須賀昭一：蒾牙交換の組織化学. 蒾界展望 $38: 9-20,1971$.

42) Lartschneider : Zweizeilige Oberkieferzyste entstanden durch zystische Entortung der beiden linken Backe Zahnfollikel, Österreichisehen garische Vierteliahrschrift Fur Zahnhelkunde. $25: 230,1909$.

43) Turner, J.G.: Two cases of hypoplasia enamel. Brit. Dent. Sci. $55: 227-228,1912$.

44) Siegmund, H. und Weber, R. : Pathologische Histologie der Mundhöhle. Leipzig, 1926.

45) Bauer, W. : Über die Entsehung der sogennanten “Turnerzähne”. Z. Stomat. 33:1090-1096, 1932.

46) Morningstar, C. : Effect of infection of the deciduous molar on the permanent tooth germ. J. Amer. Dent. Assoc. $24: 786-791,1937$.

47) Hals, E. and Orlow, M. : Turner teeth. Odont. T. $66: 199-212,1958$.

48）大塚軲美：乳歯の実験的根端性歯牙支持組織炎が永久歯粜牙に及ぼす影響に関する知見補遺（その一）歯 科学報 $54: 1-10,63-71,1954$.

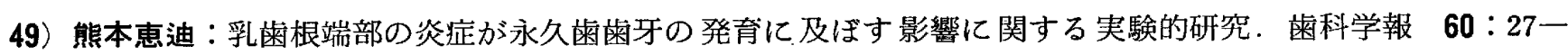
$45,689-704,1960$.

50）松本光吉・首藤 実・原田美恵子・柏木末男・永沢 亘：乳柬根尖病坚が根尖部, 根尖菌周組織, 後続永久 歯歯胚に及ぼす影響に関する実験病理組織学的研究。小巟霜誌 $15: 46$ - $51,1977$.

51) Massler, M. and Schour, I. : Studies in tooth development: Theories of eruption. Amer. J. Orthodont and Oral Surg. $27: 552-576,1941$.

52) Ten Cate, A.R. : Mechanism of tooth eruptin. In Biology of the periodontium (Melcher, A. H. and Bowen, W.H.). Academic Press, London and New York, 1969, 91-103.

53) Ness, A.R. : in "The Mechanisms of Tooth Support" (ed. by Anderson, D.J., Eastoe, J.E., Melcher, A.H. and Picton, D.C.A.) . J. Wright and Sons Ltd. Bristol., England, 8488,1967

54) Main, J.H.P and Adams, D. : Experiments on the rat incisor tee cellular proliferation and blood pressure theories of tooth eruption, Archs. Oral. Biol. $11: 163-178,1966$.

55) Thomas, N.R. : The propeties of collagen in the periodontium of an erupting tooth in the mechanisms of tooth support. J.Wright and Sons. Bristol., 1967, 102-106. 